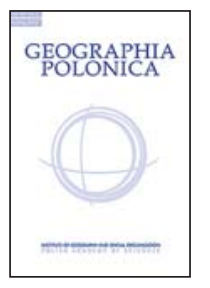

\title{
STRUCTURAL CHANGES IN POLISH INDUSTRY AFTER 1989
}

\section{Tomasz Rachwał}

Institute of Geography

Pedagogical University of Kraków

Podchorążych 2, 30-084 Kraków: Poland

e-mail: T.Rachwal@up.krakow.pl

\begin{abstract}
It has been 25 years since the beginning of the economic transformation in Poland and other countries of Central and Eastern Europe, associated with the change of the centrally controlled system over economy towards an economy based on market rules. Those changes, taking place in the conditions of globalisation of the world economy and European integration, and in recent years also the global recession, affect previously developed socio-economic structures, including the structures of industry. The aim of the article is to present changes in the role of industry in the economy of Poland, transformation of the ownership, branch and spatial structure of the industry of Poland and its diversification in regional and supra-regional systems as well as to attempt to answer the question of how the processes of industrial restructuring, undertaken during the years of economic transformation, contributed to its adaptation to the conditions of the market economy and improvement of its competitive position in global and European levels, including the possibility of integration into the global industrial networks.
\end{abstract}

\section{Key words}

economic transformation $\cdot \mathrm{FDI} \cdot$ industrial change $\cdot$ privatisation Polish industry $\bullet$ spatial structure

\section{Introduction}

Ongoing since 1989, the processes of economic transformation in Poland and other countries of Central and Eastern Europe, associated with the rejection of the centrally planned economy based on close links with the countries of the former Council for Mutual Economic Assistance (CMEA) under the guiding role of the Union of Soviet Socialist Republics (USSR), and the introduction of an economy based on mar- ket rules, affect the transformation of the previously developed socio-economic structures, including a variety of industrial structures, among which particularly interesting from the geographical point of view are the changes of spatial structures. These changes, leading to adaptation of the structures to the changing management rules, take place under the influence of impulses from the international environment related to the globalisation processes of the world economy, building 
a knowledge-based economy and the shift from the industrial and post-industrial phases to the information phase of the civilisation development. Their effect are changes in the sectoral structure of the economy, in which industrial activity, a fundamental base in the industrial phase, gives way to service activities, in particular the activities related to financial services, education, science and research and development. It should be noted, however, that this decreased role of the industry in favour of the services sector is mainly related to the activation of labour resources, not its significance in the development of civilisation. In the case of Poland and other Central European countries an important role is also played by the factors related to the influx of foreign investment and the process of European integration, which means the adjustment of national legislation and economic policies to the Community agreements and policies implemented at the European level. The consequence of this process is a change of the previous structures, mainly relating to ownership, spatial and sectoral structures of industry and its function in the economic development of spatial systems of different scales.

In light of these prerequisites, the aim of this article, based on the statistical data, is to analyse changes in the role of industry in the economy of Poland during the economic transition on the basis of its participation in the employment structure, gross output, gross value added and investment outlays, transformation of the ownership and spatial structure of the industry of Poland and its diversification in regional and supra-regional systems under the influence of internal (national) as well as international factors, relating to the inflow of direct foreign investment, as well as change in the branch structure of industry of Poland against the EU as an expression of transformation processes aimed at modernising the national industry.

The analysis includes the industry ${ }^{1}$ of Poland on a national, regional (voivodeship

1 Industry in this paper means sections C, D \& E of NACE Rev. 1.1 (till 2007) and sections B, C, D, E of
- first-tier administrative division) and supralocal (poviat - second-tier administrative division) level by branches according to the Polish code list of classification of economic activity (PKD) 2004/2007 (NACE Rev. 1.1/2.02). The sources of the data were statistical yearbooks and other publications of the Central Statistical Office (CSO), data from the Ministry of Treasury, National Bank of Poland (NBP), Polish Information and Foreign Investment Agency (PAlilZ) and United Nations Conference on Trade and Development (UNCTAD). The author encountered difficulties in accessing comparable data over the full research time (the issue of significant difficulties accessing detailed data in specific time intervals referring to the development of industry were discussed at length in previous papers of the author - Rachwał 2008, 2010a).

Based on the available data the basic indicators commonly used in economic geography were calculated, including those referring to structure and temporal changes of phenomena, as well as location quotient and concentration indicator (Czapliński et al. 2013). For comparison with other countries, the study used the results of previous research on the industry of the EU regions and the transformation of the industry of Poland against the countries of Central and Eastern Europe (incl. Kilar et al. 2008; Rachwał et al. 2008, 2009; Rachwał 2010b, 2011a,b,c, 2014; Gierańczyk \& Rachwał 2012; Kilar \& Rachwał 2014). All this allows determining the position of the industrial sector in Poland in the adjustment processes leading towards the formation of effective spatial and branch

NACE Rev.2.0 (from 2008). In case of lack comparable data by section at regional level, available data for industry together with construction data was used (thus including section F of NACE Rev. 1.1/2.0).

2 It should be noted that in the analysed period there was a change of the classification of economic activities (NACE Rev. 1 to Rev. 2.0), but the changes in this area are so small that in the case of the analyses on the level of economic sectors and sections this problem can be omitted; for the analyses by branches such direct comparisons are not possible over such a long period of time. 
structures characteristic of the most developed countries of the world.

\section{Research issues of structural changes of industry in Polish geographical literature}

The issues of transformation of industrial structures in economies in transition and building of the knowledge economy have become the focus of many researchers, representatives of various scientific disciplines, including economic geographers. A special role has been played by the work undertaken on the basis of the geography of industry, which in the period of dynamic changes of the role of industrial activity in the economy, industrial policy, as well as changes in the availability of data on the production activities, had to analyse its achievements to date and undertake the new research issues, in line with the emerging challenges, both from the methodological point of view as well as for the economic practice. After all, these studies have always served both the theoretical and cognitive purposes, but also the application processes, supporting the formulation of strategic objectives in terms of directions of economic transformation and changes in industrial policy. Generally speaking, over the 25 years of economic transformation, there have been changes in the scientific interests of Polish industrial geographers that relate to the challenges connected with the analysis of the transformation processes. This manifests itself in undertaking new fields of research and testing new methods of studying structural changes in industry. Undertaken new research problems on the basis of the geography of industry is in line with the current research and application priorities of Polish science, although it should be noted that in this regard, also in relation to spatial transformations, the studies were also undertaken by representatives of economic sciences, as indicated by Czapliński (2008).

It is worth noting that conferences in the field of industrial geography, organised annually in December by the Industrial Geography Commission of the Polish Geographical Society (Zioło \& Rachwał 2008) and the Department for Entrepreneurship and Spatial Management of the Institute of Geography at the Pedagogical University in Kraków have become a special forum for exchanging ideas and research achievements in this area (Zioło \& Rachwat 2014). The results of the research in this field were published, especially in the last 15 years, in "Studies of the Industrial Geography Commission of the Polish Geographical Society", as well as other leading journals and publication series, both national and international.

Given the time criterion, several characteristic periods need to be delimited in which changes of the research issues are visible, i.e.:

- the initial phase of the economic transformation (known as the transformation shock): 1989-1993, in which researchers focused on analysing the state of the industry at the end of the centrally planned economy and the effects of actions taken as part of 'the shock therapy' for the operation of industrial enterprises, as well as adaptation strategies of companies to new economic conditions;

- the major economic transition period: 1994-2004; during this period the research was related mainly to the assessment of the impact of different paths of privatisation of enterprises, including foreign capital inflow, on the processes of restructuring as well as industrial structural changes; moreover, the undertaken discussions were related to the assessment of the effects of 'the shock therapy' in Poland, compared to those countries in Central and Eastern Europe, where more evolutionary transition strategies were selected, as well as the impact of the creation of Special Economic Zones for the development and changes in the spatial structure of industry;

- the main phase of European integration: 2004-2007; during this period the researchers focused their attention on the issue of influx of foreign capital 
into Polish industry and also the expansion of domestic enterprises on the European markets, which was related to the inclusion of Poland to the single European market; other studies referred to the problems associated with maladjustment of the labour market structure to the challenges related to the transformation of industry; moreover, the first assessments of the effects of the economic transformation and restructuring actions were undertaken;

- the period of global economic crisis: 20082015 (?); in this period, more prominently the issue of the impact of pulses from the international environment was stressed, including those related to the construction of a knowledge-based economy and recessive phenomena in the world economy on the functioning of industry; strong attention was played to the necessity to re-industrialise the national and European economy and to a greater sectoral differentiation of the structure of the industry and increase of its innovativeness, which prepares the economy better to the crisis phenomena.

It should also be noted that the observed evolution of the research interests was in line with the stages of the economic transition and changes in the international environment, followed by maintaining the interest in the issues being the subject of many years of research of industrial geography, including the interaction between industry and natural environment as well as location factors (Zioło 1992; Parysek 1993a; Stryjakiewicz 2014).

Research in the area of change of industrial structures were taken on the basis of various methodological orientations in economic geography (Stryjakiewicz 2001a, 2014) and at all spatial levels: mega- (global and European systems), macro- (national system), meso- (regional system), as well as microeconomic, although at lower levels there are restrictions arising from the availability of the data on the structure of the industry at the local and supra-local levels as well as at the level of economic entities, as pointed out by Domański (1997) and Rachwał (2008, 2010a).

It is worth noting that the methodology studies widely accept that the issue of structural change in industry is one of the main research fields. This research current presents model approaches to structural changes in industry and the role of industry in the socio-economic space (Stryjakiewicz 1999; Zioło 2008, 2014a, b), as well as the use of selected theories and concepts to explain structural changes in industry (Stryjakiewicz 1994, 2001a,b).

The starting point for the research on structural changes is to analyse the national circumstances related to the change from the rules of the centrally planned economic system to a market economy, implemented legal instruments, especially as regards freedom of economic activity, privatisation of state enterprises and directions of industrial policy, including the restructuring programs of specific industries, as well as international conditions associated with building a knowledge-based economy, intensifying processes of globalisation and European integration as well as the recent global crisis (Rochnowski 2000; Rachwał 2003, 2013; Zioło 2010, 2013, 2014b).

Many authors, incl. Domański (1997), Zioło (2003), Rachwał (2008), emphasise how crucial from the point of view of structural analysis are the studies on functioning of the basic elements of the spatial structure of industry, i.e. industrial entities (enterprises), mainly their ownership, production and employment structure, supply and sales trends as well as costs. An important issue is also the effects of restructuring actions taken in enterprises to increase the competitiveness of Polish industry as well as multiplier effects of industrial development for the regional and local economy. Such studies, despite the difficulties in accessing individual data, were undertaken by Tobolska (1994), Parysek (1994), Jażewicz and Rydz (1994), Wiedermann (2002), Tkocz (2006), Chmurski and Wieloński (2009), Czapliński and Stawarska (2010), Czapliński $(2011,2014)$ and others. 
The analyses of changes in spatial structures of Poland's industry relate to both the entire country (by regions), as well as individual industrial districts (Gierańczyk 2000; Czepczyński 2001; Tkocz 2001; Wiedermann 2002; Domański 2002; Pakuła 2003). A major problem is the issue of the delimitation of such districts in the absence of availability of detailed data at the local level (Parysek 1993b; Gierańczyk \& Stańczyk 2001). Other current approaches to delimitation of districts based on network relationships were also indicated (Stryjakiewicz 2001b; cf. Dyba \& Stryjakiewicz 2014).

An important place in the literature is occupied by research papers on changes to the sectoral and branch structures of industry (divisions by NACE), both in Poland, and against other countries (Paszkowski 1997; Stryjakiewicz 1999; Rachwał 2011b; Gierańczyk \& Rachwał 2012; Mrozińska 2013), as well as by individual voivodeships, including in comparison with other regions of Europe (Rachwał et al. 2008, 2009), industrial centers (towns) and rural areas of the selected regions of Poland (Rochnowski 1993; Misztal 1996). From the point of view of the objectives of transformation, an important issue is the issue of changes in the ownership structure of the industry of Poland and selected regions or branches, as well as industrial investment structure (Bazydło et al. 2001), and the role of foreign investment for the restructuring process, or more broadly - structural changes (Domański 2001, 2003a,b; Piasecka 2001; Namyślak 2004; Brezdeń 2006).

Efforts were also addressed to the changes in the exports structure of Polish industry (Komornicki 2006; Wieloński 2010), which can be regarded as an effect of restructuring processes in industry, as well as change in the functioning of corporations and large enterprises, mainly their sectoral structure and spatial concentration (e.g. Domański 2003b, 2005; Gierańczyk \& Stańczyk 2003; Tobolska 2004, 2014; Śleszyński 2007, 2008, 2010, 2014; Zioło 2009, 2011; Kilar 2014, 2015; Raźniak \& Winiarczyk-Raźniak 2015). A special role is played by the issue of links between these businesses with local and regional environment (Stryjakiewicz 2005; Domański \& Gwosdz 2005; Rachwał \& Wiedermann 2008). However, it should be emphasised that despite numerous studies on this issue, as a rule, the analyses of the functioning of various corporations to a small extent relate directly to their impact on structural change of the industry in Poland.

Transformation processes in Poland and other countries of Central and Eastern Europe are also of interest to foreign researchers. These are the work relating both to the assessment of the progress and of the effects of the economic transformation and industrial restructuring (Kennedy 1997; Lee et al. 2004), as well as to particular industries (e.g. Ivan 2005; Pavlinek 2006) and industrial districts (Baranyai \& Lux 2014). Another undertaken issue refers to the changes in the spatial structures of the industry during transformation (Kiss 1999, 2002, 2004, 2007a,b; Lux 2009 a,b 2010), including those under the influence of factors related to the economic crisis (Kiss 2012; Lengyel 2014).

\section{Transformation of the role of industry in the economy}

Analysis of changes in the share of industry in the structure of employment in the years 1995-2013 indicates a slow but systematic decrease in the role of this sector in the activation of labour force (Fig. 1). In the years 1995-2011 the share of industry was reduced from over $25 \%$ to about 20\%. Two phases of transformation in this regard can be distinguished: in 1995-2000 there was a large drop in the share of industry in employment, and then in the next five years its insignificant increase followed by another period of decline. However, this growth was caused by the revaluation of the data on employment in agriculture based on the National Census, which resulted in a sharp rise in the share of industry since 2002.

However, changes in the share of industry in production (gross output), gross value added and investment outlays take a slightly 


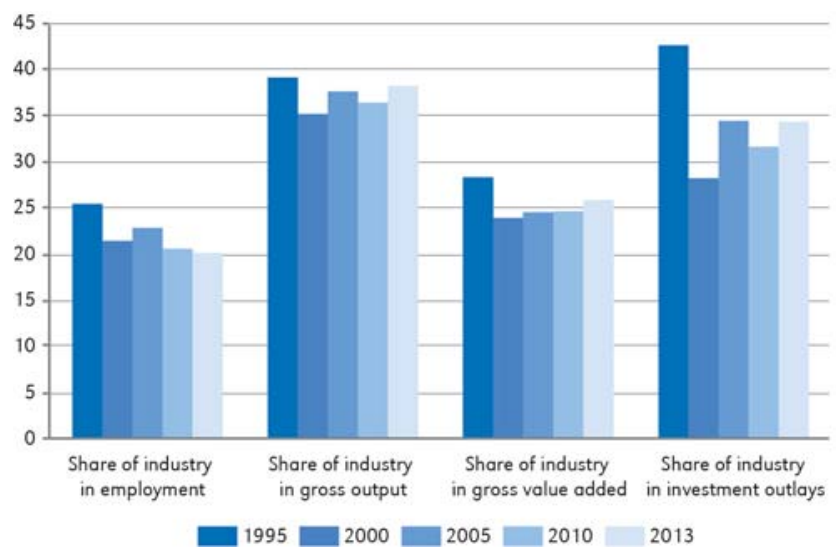

Figure 1. Changes in the share of industry in the employment structure, gross output, gross value added and investment outlays: 1995-2013

Source: compilation based on CSO data

different shape. This share is generally higher than in the case of employment, reflecting a greater role of industry in the economy measured with production and investment indicators. After a period of decrease in the share in the 1990s, which is a typical feature of countries of Central and Eastern Europe which in the conditions of the centrally planned economy implemented the program of intensive industrialisation and at the beginning of the transformation the role of industry in the economy was very high, in the twentyfirst century there was an increase observed in the shares of industry in the structure of gross output, gross added value and investment outlays.

A relatively small changes in share of industry in employment in the studied period of time influenced the fact that Poland is still among the countries of the European Union with very high shares of employment in the industrial sector compared with the 'old' EU-15 and high shares in gross value added (Rachwał 2011b,c). It should be stressed, as pointed out in earlier work (Kilar et al. 2008, Rachwał et al. 2008, 2009), that many European countries and regions continue to strengthen the potential of this sector as measured by gross value added, which does not agree with the hypothesis present in many research papers of common processes of deindustrialisation of Europe. Transformation of industrial potential is rather a confirmation of the reindustrialisation processes, in which labour-intensive industries give way to knowledge-intensive industries, characterised by higher added value, which reduces the diminishing role of industry in the immediate activation of labour resources. This is increasingly the apparent feature of the industry of countries transiting from the post-industrial phase to a knowledge-based economy. This was also pointed out by Lux (2009b), who stated that despite the observed deindustrialisation processes, the industry maintains a leading role in influencing competitiveness.

\section{Ownership transformation in the industry of Poland}

Changing management system in Poland entailed privatisation processes of enterprises. In a broad sense, according to Misztal $(1993,2003)$, this process involves the conversion of the existing industry ownership structure of the country, region, city or gmina (third-tier administrative division) in the direction of increase in the share of the private sector. It also includes the emergence of new 
private enterprises. In light of many research papers it should be understood that in the process of economic transformation privatisation in a strict sense is of particular importance, as it involves the transfer of so called 'socialised' (non-private) enterprises (state, municipal and social) or parts of them to the private sector.

Many authors indicate that privatisation is one of the basic conditions of improvement of economic efficiency and competitiveness of the company and determines attracting new investment (capital). There are also macroeconomic benefits, which include: reduced government spending (to subsidise unprofitable enterprises), increased state revenue (from sale of businesses), and consequently improved quality of goods and services (Bałtowski 2002). Misztal $(2000,2003)$ points out that without the privatisation of most of the productive potential of industry, the smooth functioning of the market economy in the region does not seem possible, as confirmed by the experience of many countries and regions in the world. However, the results of the studies of Tichá (2012) on privatisation in transition economies suggest that private ownership is an important but not sufficient determinant of firm prosperity.

Misztal $(1993,2003)$ notes that the privatisation process of industry in a broad sense began in Poland in the 1980s, thanks to the resolution of the Council of Ministers of 1981 on the development of small manufacturing, which ended a period of discrimination of craft and limitations to its development. Of course pace of privatisation has clearly risen since 1989 with the adoption of the relevant laws, primarily the Law on privatisation of state-owned enterprises (13 July 1990). This was an essential legal instrument governing the procedure of privatisation of state enterprises in the initial period of transformation (1990-1996 and the first quarter of 1997). Later it was replaced by new laws governing privatisation processes. Based on existing laws on the privatisation of state enterprises in Poland there are three basic paths to the proceedings:
1. Capital privatisation - indirect, transforming a state enterprise into a sole shareholder of the State Treasury (commercialisation) and the deployment of shares to third parties or transformation of the enterprise into a company with creditors' participation in the conversion of debt into shares. This path of privatisation was to have been selected for large and medium-sized enterprises in good financial condition. In the light of the literature it should be noted that this is the most preferred method of privatisation for the state budget (due to income from the sale of shares), as well as for the company, as the strategic investor most often accepts additional commitments concerning the size of the investment, capital increase, the level of employment and others.

2. Direct privatisation, involving the sale or lease of its property in whole or in part to private entities. This manner of privatisation was to concern primarily smaller companies and is also applicable in the case of the enterprises with relatively good financial condition.

3. Liquidation of the company for economic reasons.

In 1995, in the framework of indirect privatisation procedure, a unique program in Central and Eastern Europe of mass privatisation was launched, which consisted in creating National Investment Funds (NFI). The program was designed to accelerate and extend the scope of the ownership transformation. However, from its outset it aroused many doubts and controversies, even among its creators. It has not fulfilled the function of universal enfranchisement, even though a large part of the society was allowed to take part in it through the purchase of share certificates (Szczepkowska 2003). The list of defects of the program mentioned in the literature is very long. The most important of them, by Karpińska-Mizielińska and Smuga (1995), include the delay in the implementation and over-complication; setting up the implementation of often conflicting objectives, since the emphasis was mainly on the function of enfranchisement, and from 
the prospects for the economy the most desirable is the restructuring function; extending it to the companies which had not yet been able to adapt to the changing environment; the differences in economic and financial condition of companies participating in the program $(1 / 3$ of them brought losses at the start of the program); and little interest on the part of foreign capital. Szczepkowska (2003) also points out that the NFI formed as conglomerates (diversified companies) as a result of random rather than the market selection, which further highlights the originality of this path of privatisation. As it turned out this had a negative impact on the functioning of enterprises under the NFI. However, the NFI program can be considered as one of the group modes of privatisation of state assets. Because of their relatively small scale (512 enterprises, without the largest industrial enterprises) it has not contributed to the rapid privatisation of the industrial sector. There are also noticeable achievements in the restructuring of most of the companies that became part of the $\mathrm{NFI}$, although taking into account the cost of the project (including consultancy), the same results could have probably been achieved with lower cost (Szczepkowska 2003). The negative effects of mass privatisation programs in many post-communist countries were pointed out by Hamm et al. (2012). It should also be noted, by Śleszyński (2007), that the pace of privatisation processes was different for the different economic sectors: services were privatised quickest (especially trade), the slowest - the so-called heavy industries and power engineering, which are capital-intensive for technological restructuring.

Despite numerous problems of privatisation, occurring especially in the case of large and strategic enterprises, as well as mistakes (including wrong choices of strategic investors), this process can be considered almost finished, and its scale and effects have so far been satisfactory. In the years 1990-2012 the privatisation process included $7551 \mathrm{com}$ panies from 8453 state-owned enterprises operating in 1990, including state-owned farms (Fig. 2). The greatest concentration of these transformations was in the years 1990-1995, when over 500 state-enterprises were subjected to privatisation annually. In total, by the end of 2012, direct privatisation included 2118 state-owned enterprises, and in 1127 of them the process of liquidation ended.

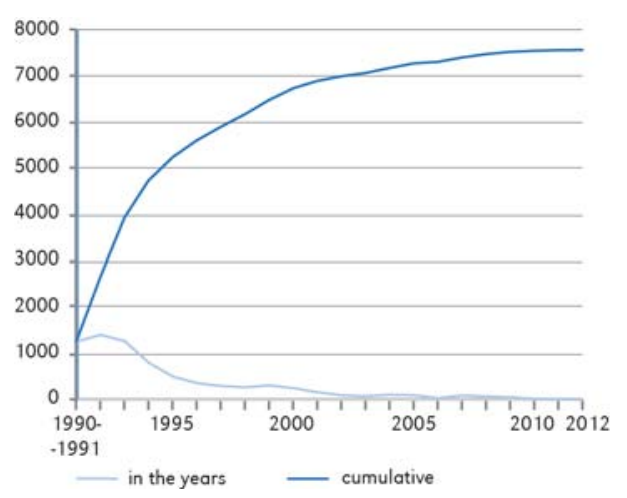

Figure 2. State owned enterprises undergoing ownership transformation: 1990-2012

Source: compilation based on CSO data

As a result of the commercialisation of state enterprises 1710 companies were founded in the years 1990-2012, including 607 privatised indirectly. In the years 1990 2012 as many as 261 companies were established with the Treasury as a result of the contribution of assets of state enterprises, including 59 with foreign capital, as well as 1563 created employee companies (CSO as of 2013). The remaining part included the liquidated state-owned agricultural enterprises whose property became part of the Agricultural Property Stock of the State Treasury.

Of course, among the commercialised state-owned enterprises many remained in the hands of the Treasury. As of 31 December 2014, the Minister of the Treasury exercised rights to the shares of 233 operating companies, of which in 98 companies the share of the State Treasury was 100\%, in 33 companies the State Treasury held a majority stake, while in 102 companies State Treasury held a minority stake (MSP 2015). The process of privatisation in the 
strict sense is thus not complete, because nearly 100 companies represent the State Treasury single company, most of which will be sold to the private sector. According to the adopted policy of privatisation, ultimately the State Treasury is to keep shares only of a few geopolitically and economically strategic enterprises. It should be noted that such a policy direction has been much criticised in the literature; it was pointed mainly on the efficiency of the state-owned companies in the interwar period and contemporary French companies investing in Poland with a large share of the French State in the shareholding.

A significant part of the companies subject to ownership transformation were industrial companies, which resulted from the fact that in Polish conditions many service enterprises (e.g. commercial), fine crafts and - above all - agriculture, even in the times of socialist economy remained in private hands (contrary to many other countries in the region, particularly former USSR republics). In the years 1990-2011 the ownership transformation processes covered 5897 businesses (excluding farms), of which 2870 i.e. almost 50\% were industrial enterprises (Tab. 1). In this group, the majority were companies representing manufacturing - nearly $90 \%$ of the total. The largest group were those belonging to the three divisions (manufacture of machinery and equipment, food products and other nonmetallic mineral products), which accounted for nearly $40 \%$ of the companies included in the section $\mathrm{C}$ - Manufacturing. It can

Table 1. State owned enterprises undergoing ownership transformation until 31 Dec. 2011 by NACE Rev. 2 industrial sections and major manufacturing divisions

\begin{tabular}{|c|c|c|c|c|c|}
\hline \multicolumn{2}{|c|}{ Specification } & \multirow{2}{*}{$\begin{array}{r}\text { Total }{ }^{\star} \\
5,897 \\
100.0 \% \\
\end{array}$} & \multirow{2}{*}{$\begin{array}{r}\begin{array}{c}\text { Commer- } \\
\text { cialised }\end{array} \\
1,761 \\
29.9 \% \\
\end{array}$} & \multirow{2}{*}{$\begin{array}{c}\begin{array}{c}\text { Included } \\
\text { in direct } \\
\text { privatisation }\end{array} \\
2,195 \\
37.2 \% \\
\end{array}$} & \multirow{2}{*}{$\begin{array}{c}\begin{array}{c}\text { Subject } \\
\text { to liquidation }\end{array} \\
1,941 \\
32.9 \% \\
\end{array}$} \\
\hline Total of which: & $\begin{array}{l}\text { units } \\
\text { share in total }\end{array}$ & & & & \\
\hline $\begin{array}{l}\text { Industry (section B, C, D \& } \\
\text { E of NACE Rev.2.0) }\end{array}$ & $\begin{array}{l}\text { units } \\
\text { share in total }\end{array}$ & $\begin{array}{r}2,870 \\
48.7 \%\end{array}$ & $\begin{array}{r}1,249 \\
21.2 \%\end{array}$ & $\begin{array}{r}831 \\
14.1 \% \\
\end{array}$ & $\begin{array}{r}790 \\
13.4 \%\end{array}$ \\
\hline $\begin{array}{l}\text { Manufacturing (section C) } \\
\text { manufacture of machinery } \\
\text { and equipment } \\
\text { (division 28) }\end{array}$ & $\begin{array}{l}\text { units } \\
\text { share in industry } \\
\text { units } \\
\text { share } \\
\text { in manufacturing }\end{array}$ & $\begin{array}{r}2,571 \\
89.6 \% \\
368 \\
14.3 \%\end{array}$ & $\begin{array}{r}1,053 \\
36.7 \% \\
120 \\
4.7 \%\end{array}$ & $\begin{array}{r}774 \\
27.0 \% \\
125 \\
4.9 \%\end{array}$ & $\begin{array}{r}744 \\
25.9 \% \\
123 \\
4.8 \% \\
\end{array}$ \\
\hline $\begin{array}{l}\text { manufacture of food } \\
\text { products } \\
\text { (division 10) }\end{array}$ & $\begin{array}{l}\text { units } \\
\text { share } \\
\text { in manufacturing }\end{array}$ & $\begin{array}{r}349 \\
13.6 \%\end{array}$ & $\begin{array}{r}173 \\
6.7 \%\end{array}$ & $\begin{array}{r}124 \\
4.8 \%\end{array}$ & $\begin{array}{r}52 \\
2.0 \%\end{array}$ \\
\hline $\begin{array}{l}\text { manufacture of other non- } \\
\text { metallic mineral products } \\
\text { (division 23) }\end{array}$ & $\begin{array}{l}\text { units } \\
\text { share } \\
\text { in manufacturing }\end{array}$ & $\begin{array}{r}272 \\
10.9 \%\end{array}$ & $\begin{array}{r}85 \\
3.3 \%\end{array}$ & $\begin{array}{r}81 \\
3.2 \%\end{array}$ & $\begin{array}{r}106 \\
4.1 \%\end{array}$ \\
\hline $\begin{array}{l}\text { Mining and quarrying } \\
\text { (section } B \text { ) }\end{array}$ & $\begin{array}{l}\text { units } \\
\text { share in industry }\end{array}$ & $\begin{array}{r}169 \\
5.9 \%\end{array}$ & $\begin{array}{r}104 \\
3.6 \%\end{array}$ & $\begin{array}{r}35 \\
1.2 \% \\
\end{array}$ & $\begin{array}{r}30 \\
1.1 \%\end{array}$ \\
\hline $\begin{array}{l}\text { Electricity, gas, steam and } \\
\text { air conditioning supply } \\
\text { (section D) }\end{array}$ & $\begin{array}{l}\text { units } \\
\text { share in industry }\end{array}$ & $\begin{array}{r}89 \\
3.1 \%\end{array}$ & $\begin{array}{r}81 \\
2.8 \%\end{array}$ & $\begin{array}{r}4 \\
0.1 \%\end{array}$ & $\begin{array}{r}4 \\
0.1 \%\end{array}$ \\
\hline $\begin{array}{l}\text { Water supply; sewerage, } \\
\text { waste management and } \\
\text { remediation activities } \\
\text { (section E) }\end{array}$ & $\begin{array}{l}\text { units } \\
\text { share in industry }\end{array}$ & $\begin{array}{r}41 \\
1.4 \%\end{array}$ & $\begin{array}{r}11 \\
0.4 \%\end{array}$ & $\begin{array}{r}18 \\
0.6 \%\end{array}$ & $\begin{array}{r}12 \\
0.4 \%\end{array}$ \\
\hline
\end{tabular}

*Without state farms incorporated into the Agricultural Property Stock of the State Treasury.

Source: compilation based on CSO data 
be noticed that all three major privatisation paths were equally applied, although in the industry the domination of commercialisation for later direct privatisation is noticeable, which was more often used for larger enterprises. An important role in the process of privatisation of industries was played by foreign capital (Domański 2001), not only in Poland, but also in other Central and Eastern Europe countries (Michalíková \& Galeotti 2011).

\section{Role of foreign capital in restructuring and changes in the industrial structures}

The industrialisation model implemented under the centrally planned economy, based primarily on capital-intensive heavy industry with the dominance of large and very large enterprises, substantially different from the model implemented in the 1970s and 80 s in Western Europe, led to a structural gap between the industries of Poland and Western economies (Wieloński 2000). Thus, the integration with Western Europe creates the necessity of eliminating this gap, i.e. by increasing efficiency, innovativeness and competitiveness of industries. However, in the transformation years the extent of these changes was limited by a lack of significant financial resources, both public (enabling pro-active industrial policy) and private (determining inclusion on a larger scale in the restructuring process). To a large extent, the liquidation of the structural gaps depended on foreign capital (Wieloński \& Durydiwka 1994). So it was necessary to open the economy to the influx of this capital. As part of the share of foreign capital in the reconstruction of the Polish economy it was primarily expected new jobs will be created, productive apparatus modernised and expanded, new technologies transferred, corporate governance improved, supply to the domestic market increased and diversified, as well as balance of trade and payments of the country improved (Karpiński 1994). The expected benefits in relation to industrial enterprises were mainly as follows:
- ownership restructuring of enterprises, assisting privatisation, preventing bankruptcy;

- improving the qualifications of employees and creating better working conditions, as well as increasing remuneration;

- introducing modern production technologies that enhance efficiency of economic activity, less negatively affecting the natural environment, through which it is possible to increase the competitiveness of the quality of products;

- enabling easier access to world markets and integrating with the global industry by entering into the existing networks of international production and sales corporations.

As Holland and Pain (1998), Pavlinek (2004) and Kiss (2007) noted, FDI has played a relevant role in the post-communist economic transformation of Central and Eastern European countries. Since the beginning of the economic transformation Poland enjoyed a relatively high interest of foreign capital. Until the global economic crisis, i.e. 2007, there was a strong upward trend in the inflow of direct foreign investment to Poland (Fig. 3). A clear collapse took place in 2008 and later in 2012. Recent data according to UNCTAD for 2013, calculated according to the new methodology indicate negative values, which mean that the value of investments withdrawn that year exceeds the inflow of investments.

As indicated by the data on business entities with foreign capital, both the number of entities (Fig. 4A) and the number of their employees (Fig. 4B) as well as the value of capital (Fig. 4C), were systematically growing in the years 2000-2013. A slight decline was only observed in 2008-2009. They are an important part of the economy, since in 2013 they employed over $11 \%$ of the total, i.e. more than 1.4 million employees. About half of the workforce is employed in industrial enterprises, although the growth rate of the entities representing the industrial sector is lower than the total. 


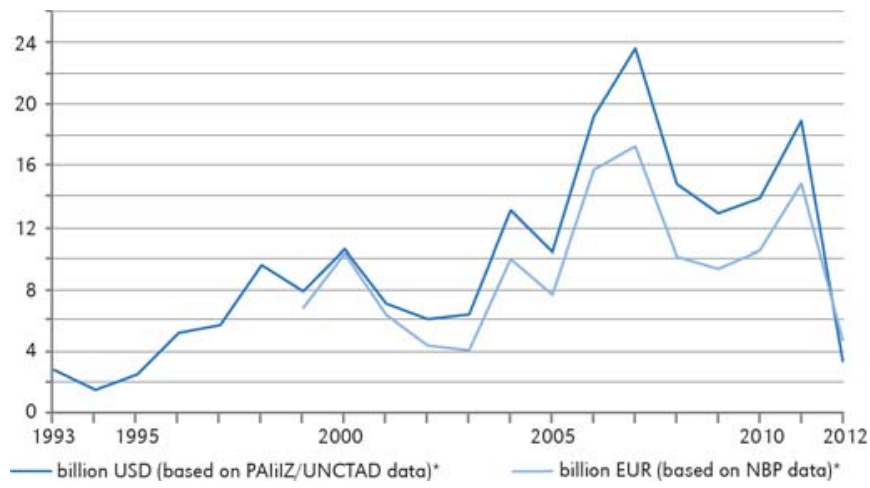

Figure 3. Inflow of foreign direct investment (FDI) to Poland: 1993-2012

* Note: there are methodological differences in calculating the data, also due to major methodological changes the data published by these institutions since 2013 may not be directly comparable Source: own compilation based on PAlilZ, UNCTAD and NBP data
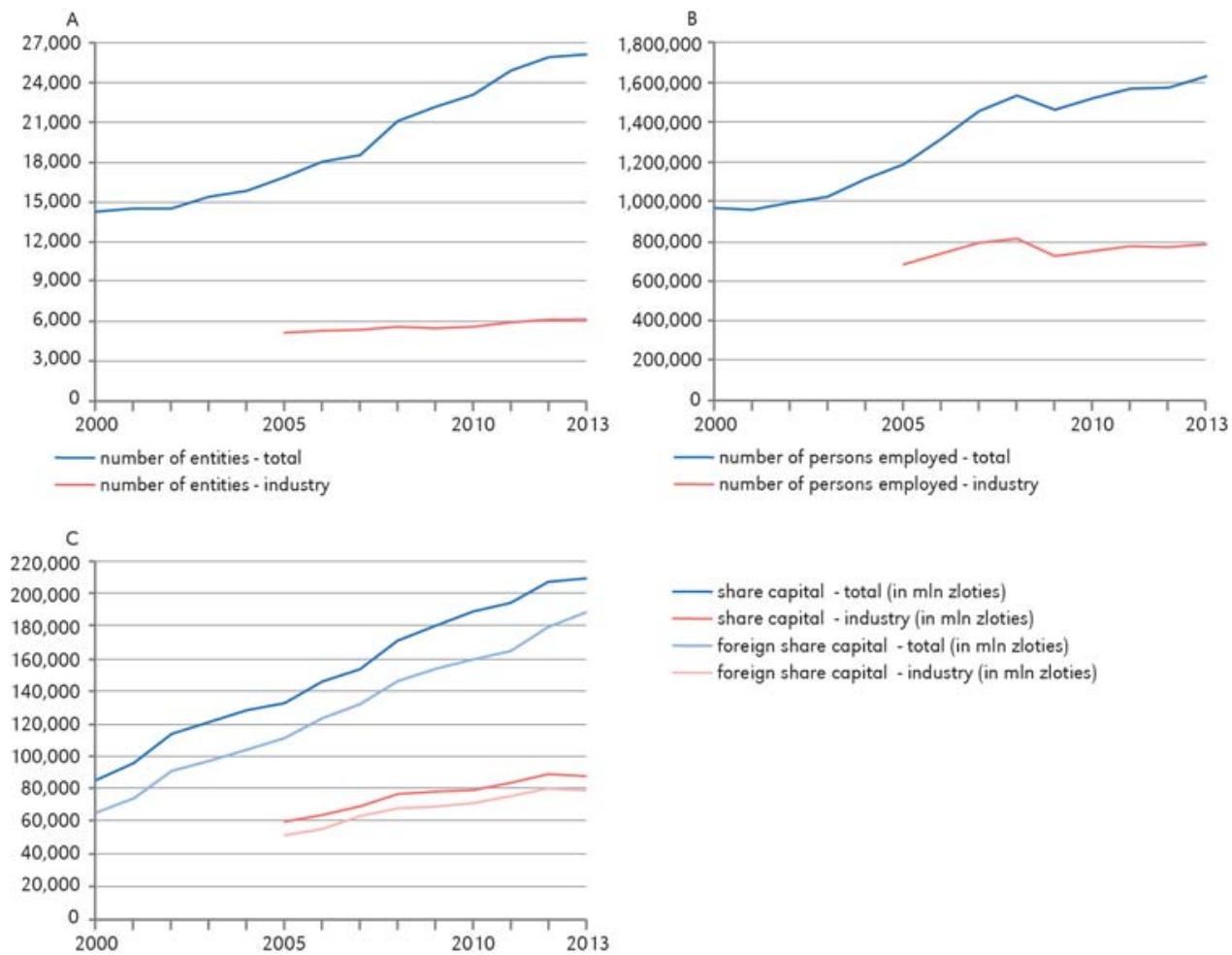

Figure 4. Activity of entities with foreign capital in Poland: number of entities (A), persons employed (B) \& share capital (C): 2000-2013

Source: compilation based on CSO data 
Analysis of the structure of total invested capital by sections and divisions of NACE indicates that since the beginning of the economic transition until 2004³ 35.6 billion, i.e. over $44 \%$ of foreign capital (single investment value of over 1 million USD) was invested in the industrial sector, including nearly $40 \%$ in industrial production, mainly in the production of transport equipment and food products, while the remainder mainly in the financial sector $-23.4 \%$, trade and repairs $11.8 \%$, as well as transport, storage manage- ment and communications - 9.7\% (Tab. 2). Additionally, the share of foreign investments in non-productive activities was systematically increasing: the share of manufacturing section declined from over $60 \%$ in the mid 1990s.

Analysis of locational preferences reveals that the biggest interest of investors was evoked by Mazowieckie Voivodeship in which the largest number of entities with foreign capital operates; the rate of such entities per 10,000 population there is over 19 (Fig. 5).

Table 2. Accumulated value of FDI in Poland according to NACE (as of 31 December 2004)

\begin{tabular}{|c|c|c|}
\hline NACE (major sections and divisions) & $\begin{array}{l}\text { Capital invested } \\
\text { (USD in millions) }\end{array}$ & $\begin{array}{l}\text { Share } \\
(\%)\end{array}$ \\
\hline Total industry & 35,636 & 44.2 \\
\hline Manufacturing & 32,200 & 39.9 \\
\hline transport equipment & 6,664 & 8.3 \\
\hline food processing & 6,625 & 8.2 \\
\hline other non-metal goods & 4,206 & 5.2 \\
\hline electrical machinery and apparatus & 3,250 & 4.0 \\
\hline chemicals and chemical products & 3,245 & 4.0 \\
\hline pulp and paper & 2,086 & 2.6 \\
\hline wood and wooden products & 1,692 & 2.1 \\
\hline rubber and plastics & 1,459 & 1.8 \\
\hline metals and metal products & 1,278 & 1.6 \\
\hline machinery and equipment & 1,024 & 1.3 \\
\hline furniture production & 350 & 0.4 \\
\hline fabrics and textiles & 291 & 0.4 \\
\hline leather and leather products & 31 & 0.0 \\
\hline Power gas and water supply & 3,208 & 4.0 \\
\hline Mining and quarrying & 229 & 0.3 \\
\hline Total services (including construction) & 44,938 & 55.7 \\
\hline Financial intermediation & 18,879 & 23.4 \\
\hline Trade and repairs & 9,517 & 11.8 \\
\hline Transport, storage and communication & 7,861 & 9.7 \\
\hline Real estate and business activities & 2,953 & 3.7 \\
\hline Community, social and personal services & 2,732 & 3.4 \\
\hline Construction & 2,110 & 2.6 \\
\hline Hotels and restaurants & 885 & 1.1 \\
\hline Agriculture & 76 & 0.1 \\
\hline Investments exceeding USD 1 million & 80,650 & 100.0 \\
\hline Estimated investments not exceeding USD 1 million & 3,828 & - \\
\hline Total & 84,478 & - \\
\hline
\end{tabular}

Source: own compilation based on PAlilZ data

\footnotetext{
3 Data by PAlilZ; later on this institution never published such detailed data
} 
In addition, large indices are recorded in the western voivodeships of Poland (Zachodniopomorskie, Lubuskie, Dolnoślaskie, Wielkopolskie) as well as Pomorskie and Śląkie. Such spatial distribution of companies with foreign capital is partly due to their location in close proximity to Germany, the country of most active investors in Poland; for historical reasons these areas also have stronger socio-economic ties with Germany.

In terms of the capital value and the number of people working in entities with foreign capital the largest and most industrialised regions in Poland dominate: firstly, Mazowieckie Voivodeship with the capital city, having almost half of the share of foreign entities and nearly $34 \%$ of the workforce, as well as Śląskie, Dolnoślaskie and Wielkopolskie (Tab. 3). Although Wielkopolskie Voivodeship in terms of the capital in foreign entities ranks only fourth (8.1\%), but in terms of the number of people employed it is in the second place, concentrating over $14 \%$ of employees in companies with foreign capital. There are thus large territorial disparities in FDI inflow into Poland. Basically, these investments are directed to the most developed regions of the country, with a high supply of skilled labour force, appropriate technical (especially transport) and social infrastructure as well as business environment, absorbent local market and where in the 1990s was a big offer of attractive companies for privatisation. The engagement of investors in less-developed regions is much lower, mainly the north-eastern Poland, i.e. Warmińsko-Mazurskie and Podlaskie voivodeships which show the highest rate of unemployment.

The result is a situation in which foreign investments do not contribute to obliterate the differences of regional development, as would be desirable, but they rather exacerbate these differences. This was not favoured, even though such were the initial assumptions, by the instrument of special economic zones which might have contributed to changes in the geography of investment flows in Poland. However, their disposition resulted from expectations of specific investors rather than conscious regional or industrial policy in terms of deconcentration of industry in Poland, which drew attention of many authors (cf. Bazydło et al. 2001; Gwosdz et al. 2005; Smętkowski 2008; Kitowski 2009).

As a result, foreign and domestic investors directed their resources mainly to traditional
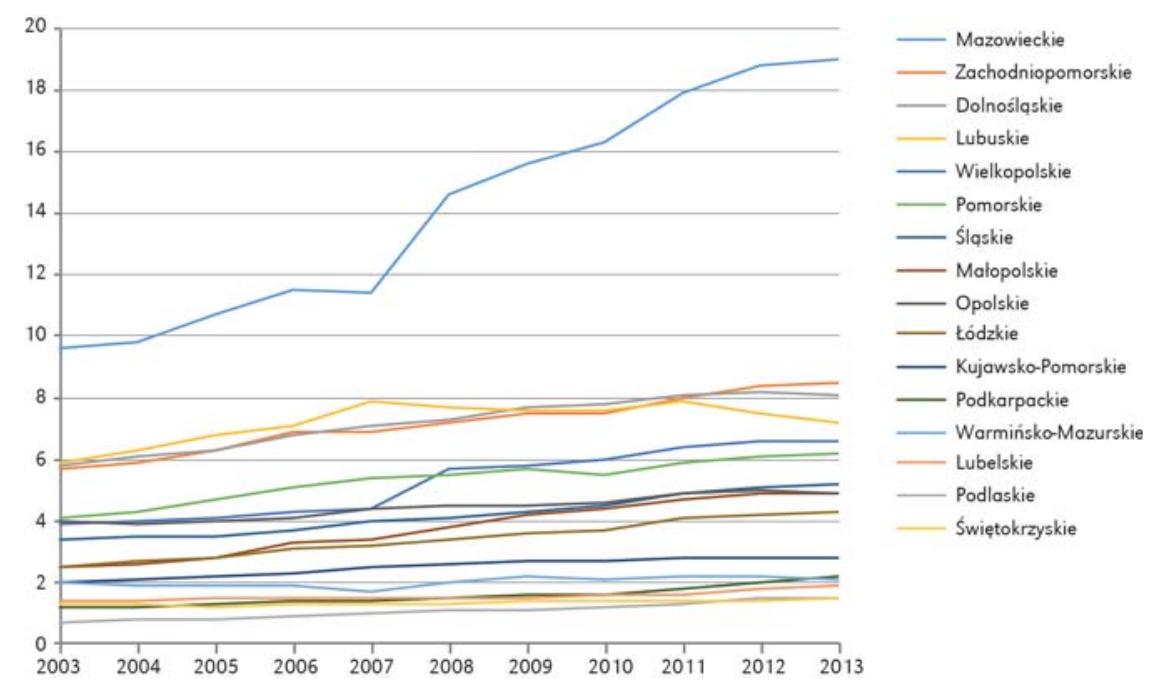

Figure 5. Entities with foreign capital per 10,000 inhabitants by voivodeships: 2003-2013

Source: compilation based on CSO data 
Table 3. Share capital and employed in entities* with foreign capital in Poland by voivodeship: 2013

\begin{tabular}{|c|c|c|c|c|c|c|}
\hline \multirow{3}{*}{ Region (voivodeship) } & \multicolumn{4}{|c|}{ Share capital } & \multirow{2}{*}{\multicolumn{2}{|c|}{ Employed persons }} \\
\hline & \multicolumn{2}{|c|}{ total } & \multirow{2}{*}{$\frac{\text { domestic }}{\text { in mn zloties }}$} & \multirow{2}{*}{$\begin{array}{c}\text { foreign } \\
\text { in mn zloties }\end{array}$} & & \\
\hline & in $\mathrm{mn}$ zloties & $\%$ & & & $\begin{array}{l}\text { number } \\
\text { in thous. }\end{array}$ & $\%$ \\
\hline Mazowieckie & 102,573 & 49.0 & 5,550 & 93,015 & 548.1 & 33.7 \\
\hline Śląskie & 19,067 & 9.1 & 3,253 & 15,635 & 181.2 & 11.1 \\
\hline Dolnośląskie & 17,365 & 8.3 & 787 & 16,136 & 155.5 & 9.5 \\
\hline Wielkopolskie & 16,889 & 8.1 & 1,011 & 15,648 & 233.6 & 14.3 \\
\hline Małopolskie & 13,592 & 6.5 & 937 & 12,472 & 104.0 & 6.4 \\
\hline Pomorskie & 8,957 & 4.3 & 2,083 & 6,735 & 61.8 & 3.8 \\
\hline Podkarpackie & 5,982 & 2.9 & 393 & 5,422 & 41.5 & 2.6 \\
\hline Zachodniopomorskie & 5,412 & 2.6 & 332 & 5,079 & 55.2 & 3.4 \\
\hline Łódzkie & 5,116 & 2.4 & 222 & 4,892 & 81.9 & 5.0 \\
\hline Kujawsko-Pomorskie & 3,101 & 1.5 & 90 & 2,990 & 37.3 & 2.3 \\
\hline Świętokrzyskie & 2,985 & 1.4 & 153 & 2,802 & 20.7 & 1.3 \\
\hline Opolskie & 2,235 & 1.1 & 139 & 2,093 & 26.2 & 1.6 \\
\hline Lubuskie & 1,957 & 0.9 & 56 & 1,899 & 34.6 & 2.1 \\
\hline Warmińsko-Mazurskie & 1,580 & 0.8 & 81 & 1,480 & 13.9 & 0.9 \\
\hline Lubelskie & 1,547 & 0.7 & 222 & 1,311 & 22.8 & 1.4 \\
\hline Podlaskie & 772 & 0.4 & 127 & 636 & 10.3 & 0.6 \\
\hline
\end{tabular}

*Note: applies to entities participating in the study by CSO; these are not all entities with foreign capital in Poland, and therefore the sum for all voivodeships cannot be compared with previously analysed data. Source: compilation based on CSO data

industrial regions and centers, attractive for investments in terms of location and infrastructure, i.e. mainly in metropolitan areas (Fig. 6). This also drew attention of other researchers, including Domański (2001) and Śleszyński (2007) - the latter observed that the urban centers of the so-called 'big five' (Warsaw, Poznań, Kraków, Tri-City, Wrocław) in 2004 had about $60 \%$ of enterprises with foreign capital. He also noted the regularity that companies with foreign capital were more often located in major metropolitan areas, and less frequently in other voivodeship capitals (Śleszyński 2007). This had of course positive effects in terms of reindustrialisation processes of these industrial areas, especially of Upper Silesia. Domański (2001) also stressed - as a result of his research on foreign capital in Polish industry - the prevalence of investment in the regions hitherto well-developed leads to widening the socio-economic polarisation. Furthermore he noted that in the 1990s these investments were rather targeted at local markets and to a lesser extent at external market, i.e. using export opportunities; an advantage of investments in existing enterprises over greenfield projects was also noticeable. In the first decade of the twenty-first century this trend was partly reversed and the 'sprawl' of inflow of investments into more peripheral areas was observed, but the concentration in metropolitan areas and in western Poland is still visible.

Considering the role of foreign capital in the restructuring of industry, we need to agree with the conclusions of Domański (2001) that, generally speaking, the balance of the effects of the inflow of foreign capital is positive for Poland's industry, although it is possible to specify individual exceptions for specific investments. Foreign investments increase the competitiveness of enterprises and of the entire economy of Poland by introducing more modern technologies and production organisation, which increase their efficiency and structural changes. 


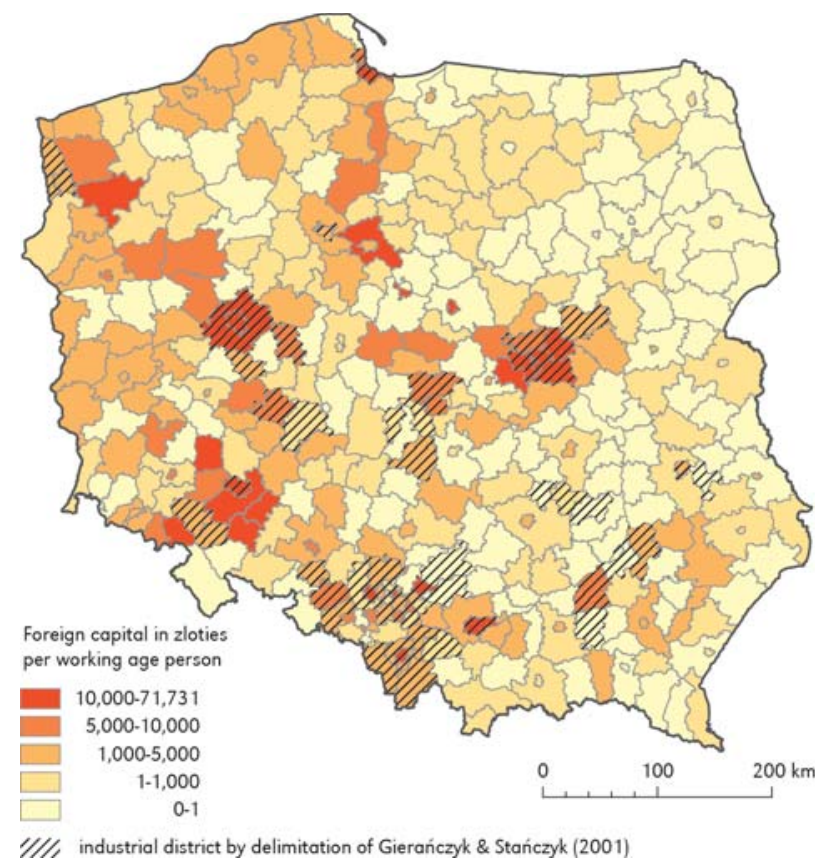

Figure 6. Foreign capital per person of working age in Poland by poviats: 2013

Source: compilation based on CSO data

Higher quality products (connected with the inclusion of Polish products into foreign market networks) trigger higher export of industrial products, especially to the European Union countries. It was confirmed by the results of Jensen's (2002) research, which indicate that FDI has affected positively the technology intensity of the Polish export base. Noteworthy is the modernisation of technology that reduces the negative impact on the environment. Investors also influence the improvement of the competitiveness of local enterprises and of staff qualifications and thus shape the comparative advantage of some cities and regions in Poland. What is important is generating additional benefits related to cooperation with local suppliers of goods and services, which affect the increase in employment in cooperating companies and thus generate the so-called multiplier effects (good examples are investments in the automotive industry in Silesia - see Rachwał \& Wiederman 2008). It should be noted that the changes in the labour market under the influence of foreign capital take place to a lesser extent by quantitative growth, but more by qualitative changes. New jobs are essentially the result of greenfield investments, while the purchase of companies by an investor was followed by a reduction of employment.

Unfavourable liquidation of plants belonging to foreign companies is quite a rare phenomenon and generally follows the transfer or concentration of production at other plants in Poland, not relocation to other countries. The beneficial effect of foreign investment was also detected in previous studies in industrial enterprises of south-eastern Poland (e.g. Rachwał 2006). They show clearly that companies taken over by foreign capital more quickly implemented restructuring strategies, modernised or changed production lines in order to improve the quality and competitiveness of products, and consequently deepened and expanded markets, also foreign, improving their financial condition. 


\section{Transformation of the branch structure of industry}

Analysis of diversity of industrial structures by the first-level classification by section, due to its structure in which nearly $90 \%$ share is in the Section Manufacturing (D by NACE Rev. 1.1, C by NACE Rev. 2.0), does not allow concluding on changes in the sectoral structure of industry in Poland. In order to capture the structural changes in industry the analysis at the level of divisions is needed, i.e. the second-level of classification. Due to significant changes at this level of classification since 2008 direct comparison with previous years is not possible.

As earlier analyses (Rachwał 2010b) indicate the highest number of workers and highest sold production value were performed by the divisions 'manufacture of food products and beverages', 'manufacture of machinery and equipment' as well as 'manufacture of metal products'. Relatively important role was played by coal mining. Modern production divisions (30 to 33 by NACE Rev. 1.1) showed a relatively low potential of employment and gross value added. Analysis of the dynamics of employment changes in industry by sections in 1995-2007 showed a large, more than twofold increase in employment in the divisions 'manufacture of office machinery and computers' and 'waste treatment', but one needs to be aware of negligible importance of these sectors in the employment potential (employment in a base year was very low).

The largest decrease in employment and sold production value (even by 50\%) was recorded in the traditional industrial sectors, such as mining, textiles, manufacture of clothing, leather and related products. This is an obvious consequence of the diminishing role of coal and lignite in the economy and - since the 1990s - systematic losing the position by Poland as a country with low production costs, which are crucial in the case of textiles and clothing production. Different dynamics of change in the various sectors meant that in those years there occurred significant changes in the share of individual divisions in the structure of employment and sold industrial production. The most traditional, labour-intensive industries, such as mining, manufacture of clothes, textiles and leather products, but also the production of machinery and equipment, energy and chemical industries lost their importance. The share of such sections as manufacture of metal, rubber and plastic products, manufacture of furniture and motor vehicles increased significantly in the structure. It is difficult though to include these divisions to the industries most advanced technologically. It seems this is the reflection of large investment of foreign capital in those sectors of industry, particularly in the automotive industry (Domański et al. 2005, 2008, 2013; Pavlínek 2006; Pavlínek et al. 2009; Wójtowicz \& Rachwał 2014).

Available data on the structure of employment in industry by sections of NACE Rev. 2.0 in the period 2005-2013 point to a continuation of these trends. On the one hand, there is still a considerable drop in the share of traditional industries, such as manufacture of clothing and textile goods, while the share of manufacture of metal products, electrical appliances, rubber products and motor vehicles is growing in the structure (Tab. 4). These changes should be seen as a positive expression of reindustrialisation processes and adaptation of the Polish industry to the conditions and development of innovative knowledge-based economy.

As indicated by earlier analyses (Rachwał 2010b, 2011b), the sectoral structure of the Polish industry in transition is conforming to the structure of some more economically developed EU countries, although back in the 1990s it was more similar to other countries of Central and Eastern Europe.

\section{Transformation of the spatial structure of the industry of Poland}

Spatial structure of industry, especially in the regional setting, shows certain inertia associated with relatively high stability of the 
existing industrial potential in the region and a relatively slow investment process. Analysis of the share of voivodeships in the structure of employment in industry and construction in 1995-2007 (Fig. 3) indicates a large share of the traditionally highly industrialised voivodeships: Śląkie, Mazowieckie and Wielkopolskie. However, Ślqskie Voivodeship significantly reduced its share in the national potential of employed in industry from over $20 \%$ to less than $17 \%$; similarly, a rather significant drop of more than one percentage point was recorded for Mazowieckie, whereas Wielkopolskie increased its share significantly. High and increasing share of industry in employment is also recorded by Dolnośląskie. This is a consequence of intensive development of industry in the first decade of the twenty-first century in the metropolitan areas of Poznań (cf. Wdowicka 2002) and Wrocław (cf. Brezdeń 2006).

Analysis of location quotients (Lq) for those working in industry and construction indicates that the largest concentration of industrial activity occurs in the south-western and central voivodeships of Poland, particularly in Śląskie, Dolnośląskie, Wielkopolskie, Małopolskie and Łódzkie (Fig. 8A). These are the regions traditionally highly industrialised, such as Śląskie Voivodeship undergoing reindustrialisation, and those in which in the years of transition many new investments were located, mainly of foreign capital, in the medium tech industries, e.g. automotive industry or the production of household appliances, particularly in the metropolitan areas of Poznań, Wrocław and Łódź.

In the analysed period of time the biggest drop in the value of the quotient was found in Ślaskie Voivodeship, while the biggest increase was recorded in Wielkopolskie; however, the image of the spatial structure remains virtually the same, because the changes are small (Fig. 8B).

The structure of the industry by sold production index by voivodeship is slightly different. The largest share is represented by Mazowieckie Voivodeship, in which, similarly to Wielkopolskie, Dolnośląskie and Pomorskie, there was a large increase in the share (Fig. 9). It is the effect of the location of new investment and growth of more

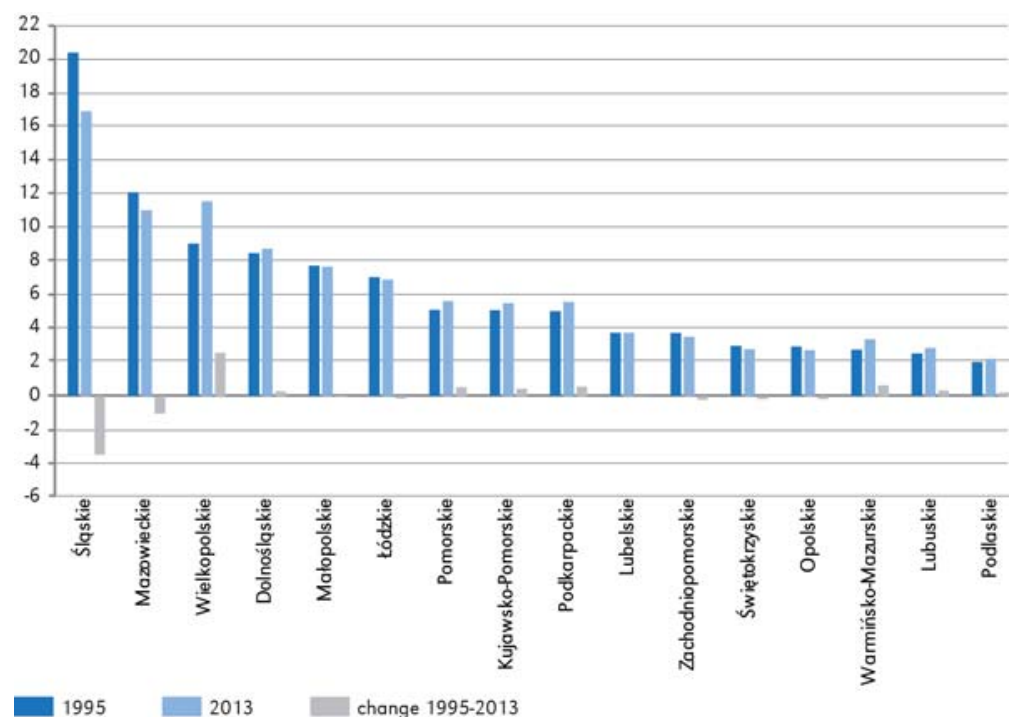

Figure 7. Changes in the employment structure of industry and construction by voivodeships: 1995 to 2013

Source: compilation based on CSO data 
Table 4. Production sold and employment in industry by the NACE Rev. 2.0 division

\begin{tabular}{|c|c|c|c|c|c|c|c|c|c|c|c|c|}
\hline \multirow{3}{*}{$\begin{array}{c}\text { NACE Rev. } 2.0 \text { divisions of in- } \\
\text { dustry }\end{array}$} & \multicolumn{6}{|c|}{ Production sold (current prices) } & \multicolumn{6}{|c|}{ Employed persons } \\
\hline & \multicolumn{2}{|c|}{ in mln zloties } & \multirow{2}{*}{$\begin{array}{l}\text { dynamics } \\
2005=100\end{array}$} & \multicolumn{2}{|c|}{$\%$} & \multirow{2}{*}{$\begin{array}{c}\text { change } \\
\text { in share } \\
\text { (pp.) }\end{array}$} & \multicolumn{2}{|c|}{ in thous. } & \multirow{2}{*}{\begin{tabular}{|l|} 
dynamics \\
$2005=100$
\end{tabular}} & \multicolumn{2}{|c|}{$\%$} & \multirow{2}{*}{$\begin{array}{c}\text { change } \\
\text { in share } \\
(p p)\end{array}$} \\
\hline & 2005 & 2013 & & 2005 & 2013 & & 2005 & 2013 & & 2005 & 2013 & \\
\hline $\begin{array}{l}\text { Industry TOTAL (section B-E; } \\
\text { division 5-39) }\end{array}$ & 687,810 & $1,182,964$ & 172.0 & 100.0 & 100.0 & - & $2,857.6$ & $2,872.2$ & 100.5 & 100.0 & 100.0 & - \\
\hline $\begin{array}{l}\text { Mining and quarrying (divisions } \\
5-9)\end{array}$ & 357 & 180 & 50.5 & 5.1 & 4.8 & -0.3 & 186.4 & 168.6 & 90.5 & 6.5 & 5.9 & -0.6 \\
\hline $\begin{array}{l}\text { Manufacture of food products } \\
\text { (10) }\end{array}$ & 106,689 & 182,707 & 171.3 & 15.5 & 15.4 & -0.1 & 417.1 & 405.2 & 97.1 & 14.6 & 14.1 & -0.5 \\
\hline Manufacture of beverages (11) & 14,865 & 19,553 & 131.5 & 2.2 & 1.6 & -0.6 & 34.0 & 24.1 & 70.9 & 1.2 & 0.8 & -0.4 \\
\hline $\begin{array}{l}\text { Manufacture of tobacco } \\
\text { products (12) }\end{array}$ & 3,629 & 3,656 & 100.7 & 0.5 & 0.3 & -0.2 & 7.1 & 5.8 & 81.7 & 0.2 & 0.2 & 0.0 \\
\hline Manufacture of textiles (13) & 7,680 & 10,399 & 135.4 & 1.1 & 0.9 & -0.2 & 62.2 & 50.0 & 80.4 & 2.2 & 1.7 & -0.5 \\
\hline $\begin{array}{l}\text { Manufacture of wearing ap- } \\
\text { parel (14) }\end{array}$ & 9,249 & 8,124 & 87.8 & 1.4 & 0.7 & -0.7 & 183.7 & 100.9 & 54.9 & 6.4 & 3.5 & -2.9 \\
\hline $\begin{array}{l}\text { Manufacture of leather and } \\
\text { related products (15) }\end{array}$ & 2,979 & 4,192 & 140.7 & 0.4 & 0.4 & 0.0 & 35.6 & 26.0 & 73.0 & 1.2 & 1.0 & -0.2 \\
\hline $\begin{array}{l}\text { Manufacture of products } \\
\text { of wood, cork, straw and } \\
\text { wicker (16) }\end{array}$ & 20,123 & 30,818 & 153.1 & 2.9 & 2.6 & -0.3 & 128.6 & 119.5 & 92.9 & 4.5 & 4.2 & -0.3 \\
\hline $\begin{array}{l}\text { Manufacture of paper and } \\
\text { paper products (17) }\end{array}$ & 16,743 & 31,858 & 190.3 & 2.4 & 2.7 & 0.3 & 47.9 & 56.7 & 118.4 & 1.7 & 2.0 & 0.3 \\
\hline $\begin{array}{l}\text { Printing and reproduction } \\
\text { of recorded media (18) }\end{array}$ & 8,027 & 12,401 & 154.5 & 1.2 & 1.0 & -0.2 & 43.1 & 49.7 & 115.3 & 1.5 & 1.7 & 0.2 \\
\hline $\begin{array}{l}\text { Manufacture of coke and re- } \\
\text { fined petroleum products (19) }\end{array}$ & 33,354 & 83,800 & 251.2 & 4.9 & 7.1 & 2.2 & 16.7 & 13.2 & 79.0 & 0.6 & 0.5 & -0.1 \\
\hline $\begin{array}{l}\text { Manufacture of chemicals and } \\
\text { chemical products }(20)\end{array}$ & 30,571 & 55,562 & 181.7 & 4.4 & 4.7 & 0.3 & 69.4 & 74.5 & 107.3 & 2.4 & 2.6 & 0.2 \\
\hline
\end{tabular}




\begin{tabular}{|c|c|c|c|c|c|c|c|c|c|c|c|c|}
\hline $\begin{array}{l}\text { Manufacture of pharmaceuti- } \\
\text { cal products (21) }\end{array}$ & 7,046 & 11,9416 & 169.5 & 1.0 & 1.0 & 0.0 & 22.9 & 21.4 & 93.4 & 0.8 & 0.7 & -0.1 \\
\hline $\begin{array}{l}\text { Manufacture of rubber and } \\
\text { plastic products (22) }\end{array}$ & 33,890 & 67,776 & 200.0 & 4.9 & 5.7 & 0.8 & 143.6 & 180.0 & 125.3 & 5.0 & 6.3 & 1.3 \\
\hline $\begin{array}{l}\text { Manufacture of other non- } \\
\text { metallic mineral products (23) }\end{array}$ & 26,997 & 42,181 & 156.2 & 3.9 & 3.6 & -0.3 & 129.2 & 125.9 & 97.4 & 4.5 & 4.4 & -0.1 \\
\hline $\begin{array}{l}\text { Manufacture of basic metals } \\
\text { (24) }\end{array}$ & 28,294 & 41,631 & 147.1 & 4.1 & 3.5 & -0.6 & 64.9 & 61.2 & 94.3 & 2.3 & 2.1 & -0.2 \\
\hline $\begin{array}{l}\text { Manufacture of metal products } \\
(25)\end{array}$ & 38,254 & 77,877 & 203.6 & 5.6 & 6.6 & 1.0 & 227.1 & 295.1 & 129.9 & 7.9 & 10.3 & 2.4 \\
\hline $\begin{array}{l}\text { Manufacture of computer, } \\
\text { electronic and optical products } \\
\text { (26) }\end{array}$ & 17,742 & 31,243 & 176.1 & 2.6 & 2.6 & 0.0 & 53.5 & 54.6 & 102.1 & 1.9 & 1.9 & 0.0 \\
\hline $\begin{array}{l}\text { Manufacture of electrical } \\
\text { equipment (27) }\end{array}$ & 19,485 & 45,699 & 234.5 & 2.8 & 3.9 & 1.1 & 78.7 & 97.7 & 124.1 & 2.8 & 3.4 & 0.6 \\
\hline $\begin{array}{l}\text { Manufacture of machinery and } \\
\text { equipment (28) }\end{array}$ & 28,377 & 36,785 & 129.6 & 4.1 & 3.1 & -1.0 & 141.5 & 123.5 & 87.3 & 5.0 & 4.3 & -0.7 \\
\hline $\begin{array}{l}\text { Manufacture of motor vehicles, } \\
\text { trailers and semi-trailers (29) }\end{array}$ & 63,658 & 109,919 & 172.7 & 9.3 & 9.3 & 0.0 & 126.9 & 164.3 & 129.5 & 4.4 & 5.7 & 1.3 \\
\hline $\begin{array}{l}\text { Manufacture of other transport } \\
\text { equipment (30) }\end{array}$ & 10,091 & 16,232 & 160.9 & 1.5 & 1.4 & -0.1 & 55.1 & 43.3 & 78.6 & 1.9 & 1.5 & -0.4 \\
\hline Manufacture of furniture (31) & 21,665 & 31,596 & 145.8 & 3.2 & 2.7 & -0.5 & 156.1 & 157.3 & 100.8 & 5.5 & 5.5 & 0.0 \\
\hline Other manufacturing (32) & 5,664 & 9,610 & 169.7 & 0.8 & 0.8 & 0.0 & 50.1 & 52.7 & 105.2 & 1.8 & 1.8 & 0.0 \\
\hline $\begin{array}{l}\text { Repair and installation of ma- } \\
\text { chinery and equipment (33) }\end{array}$ & 16,594 & 28,142 & 169.6 & 2.4 & 2.4 & 0.0 & 105.2 & 118.5 & 112.6 & 3.7 & 4.1 & 0.4 \\
\hline $\begin{array}{l}\text { Electricity, gas, steam and air } \\
\text { conditioning supply (35) }\end{array}$ & 66,401 & 102,833 & 154.9 & 9.7 & 8.7 & -1.0 & 150.5 & 137.3 & 91.2 & 5.3 & 4.8 & -0.5 \\
\hline $\begin{array}{l}\text { Water supply; sewerage, waste } \\
\text { management and remediation } \\
\text { activities (divisions 36-39) }\end{array}$ & 14,501 & 29,849 & 205.8 & 2.1 & 2.5 & 0.4 & 120.5 & 145.2 & 120.5 & 4.2 & 5.0 & 0.8 \\
\hline
\end{tabular}

Source: compilation based on CSO data 

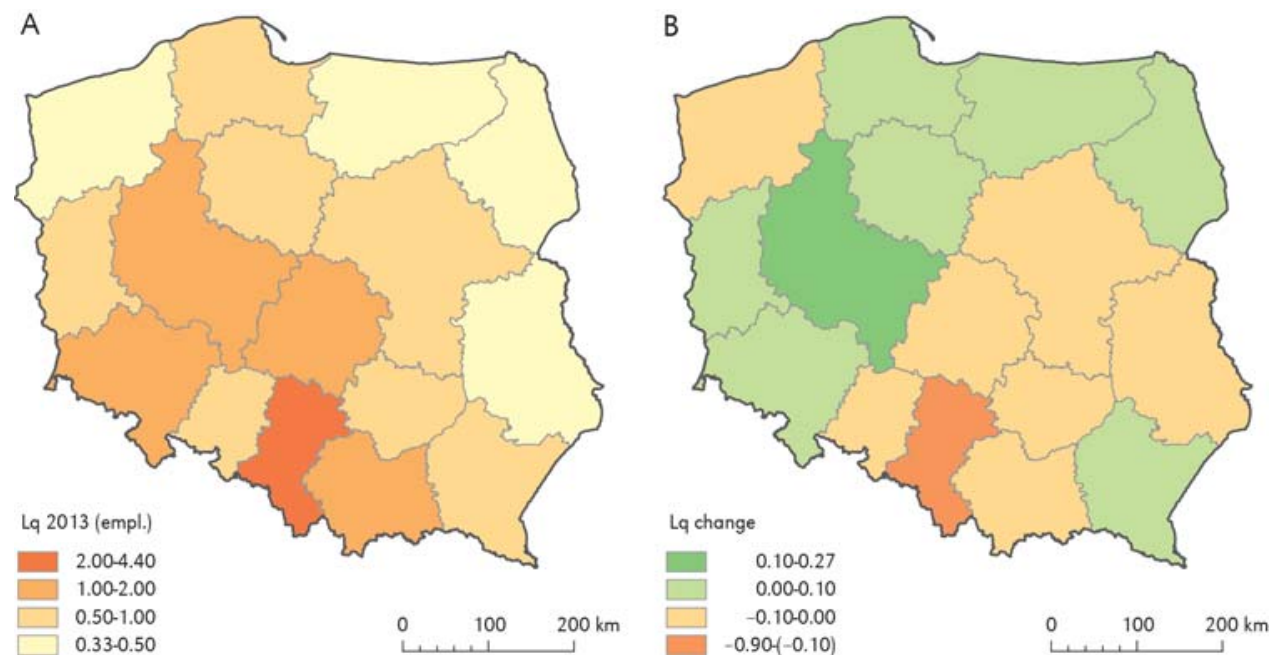

Figure 8. Location quotients for employed in industry and construction in 2013 (A) and their change: 1995-2013 (B)

Source: based on CSO data

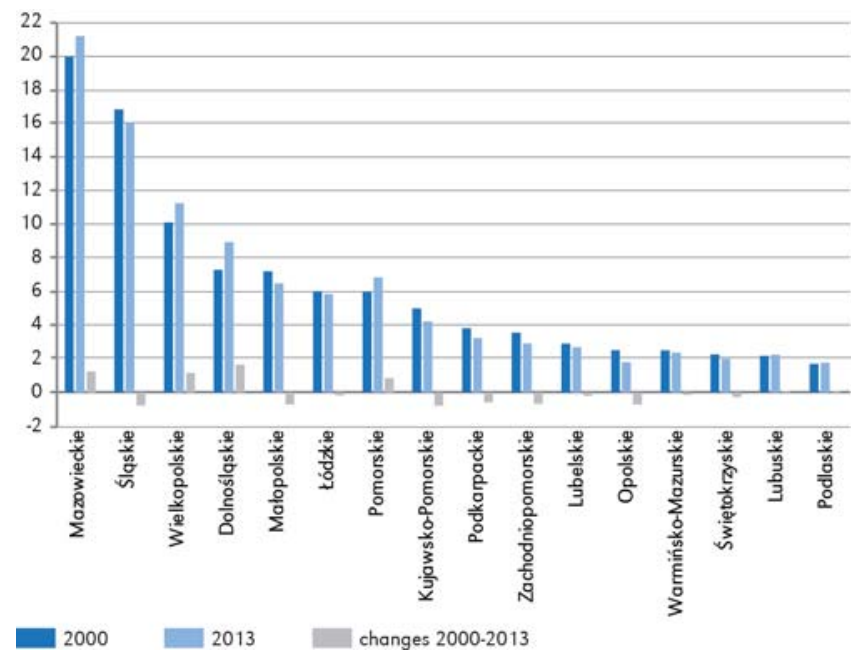

Figure 9. Changes in the structure of sold production by voivodeships: 2000-2013

Source: compilation based on CSO data

technologically advanced industries in these regions. The voivodeships losing their share in the structure of sold production include Ślqskie, Małopolskie, Opolskie, Kujawsko-Pomorskie and Zachodniopomorskie.

Analysis of location quotients for sold industrial production indicates a somewhat different spatial picture than that of the employment ratio (Fig. 10A). First of all, the indices are slightly higher (for a better view the maps preserved the same colour scale), and the voivodeships with relatively high Lq also include Mazowieckie and Pomorskie. It should also be noted that the changes 
of location quotients in the period 20002013 are low (Fig. 10B). Larger declines in the value of the quotient were recorded primarily in Śląskie Voivodeship and other regions of southern Poland, as well as in KujawskoPomorskie, while the growth was recorded in such voivodeships as Wielkopolskie, Dolnośląskie, Pomorskie and Mazowieckie, which observed the location and dynamic development of more technologically advanced industrial enterprises.

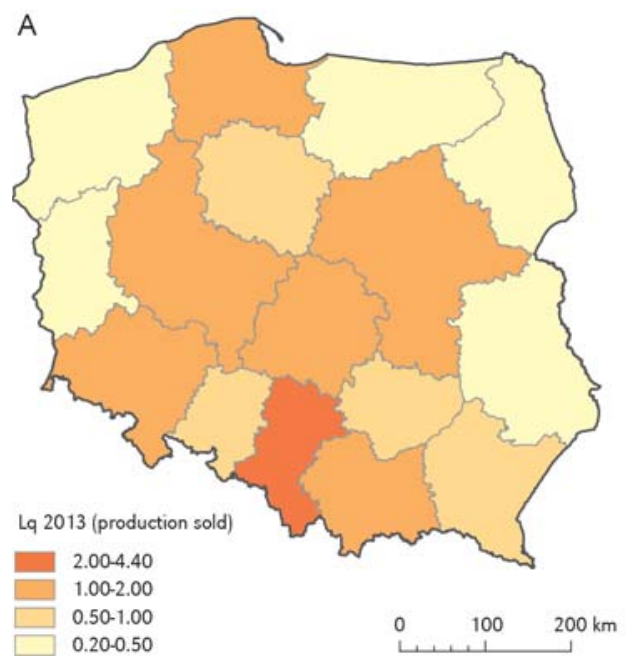

current 16 and former 49 voivodeships. Traditionally, high rates are recorded in Upper Silesia and in other metropolitan areas: Poznań, Wrocław, Łódź, Warsaw and Kraków. This refers to the traditional industrial districts of Poland though, as pointed by Gierańczyk and Stańczyk (2001), the ranges of these districts are shrinking, and some of them disappeared in light of the adopted traditional criteria of delimitation.

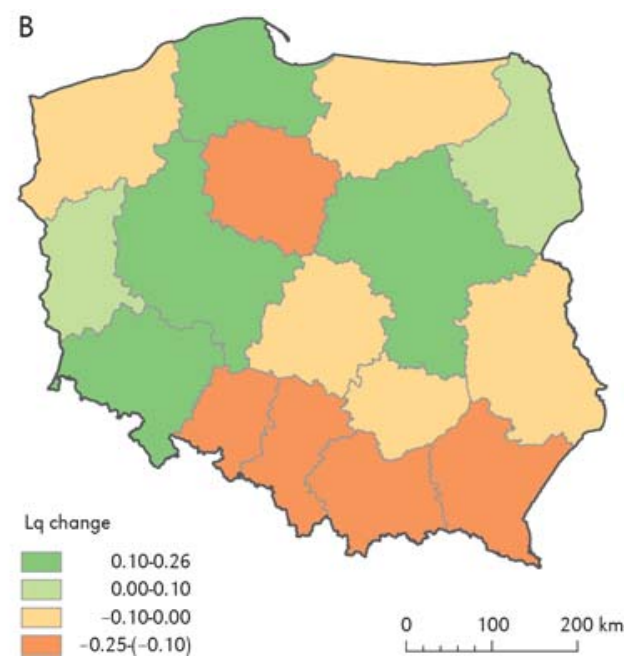

Figure 10. Location quotients for sold industrial production in 2013 (A) and their change: 2000-2013 (B) Source: study based on CSO data

The calculated coefficient of localisation (Florence's concentration index) suggest a slight increase of concentration of the industry by voivodeships, and in the case of sold production these indices are higher than in the case of a number of employees. This indicates a higher degree of concentration of technologically more advanced industries of high value of sold industrial production. The analysis of location quotients at supralocal level (poviats) indicates high concentration of industry in the traditionally shaped industrial districts and centers, even in the period of central control over the economy (Fig. 11). High rates of Lq both for employed in industry and construction as well as of sold production are primarily in the capitals of the

\section{Conclusions}

The analysis of structural changes of the industry of Poland and changes in the role of this sector in the economy of the country in the period of economic transformation allows drawing the following conclusions:

- ownership changes in the industry of Poland led to a situation in which the majority of companies operating before 1989 were privatised; to a large extent, this was done with the participation of foreign capital due to the limited resources of the national capital, especially in the initial period of transformation;

- generally speaking, as shown by previous studies, privatisation has contributed 

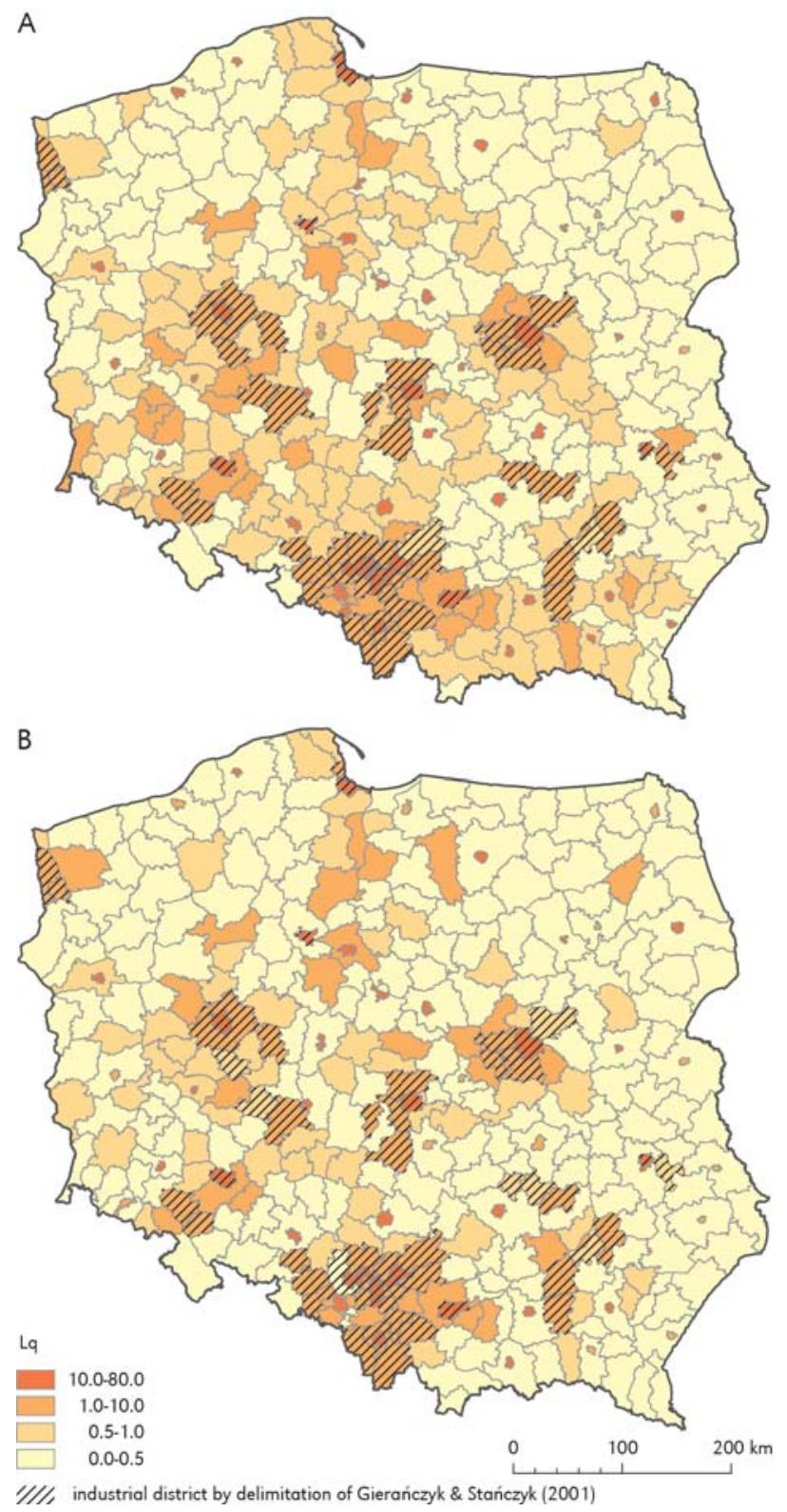

Figure 11. Location quotients for employed in industry and construction (A) and sold industrial production (B) by poviats against delimitation of industrial districts in 2011

Source: study based on CSO data (Rachwał 2014)

to faster and more efficient implementation of restructuring strategies, especially in the modernisation of technology and range of products as well as increase in labour productivity and improvement in the financial condition and competitive position of the industrial enterprises created before 1989;

- the share of industry in the structure of employment, gross output, gross added 
value and investment outlays in Poland shows a downward trend, as in most EU countries (as shown by earlier studies), however, a slight increase in this share was recorded after 2000 in the case of production indicators; Poland still belongs to the EU countries with a high share of industry in the economy;

- the share of industry in gross value added is several percentage points higher than the share of industry in the structure of employment, reflecting the diminishing importance of the industry in activation of labour resources, while maintaining its role as the economic base;

- in the structure of employment and sold production in the transition period the traditional sectors, like mining, textiles, metal production, or clothing, lose importance which is associated with the relocation of this type of activity to the countries with lower labour costs; this trend, from the point of view of the objectives of the reindustrialisation and the construction of the knowledge-based economy in Poland, should be seen as positive;

- in the light of previous studies it should be noted that changes in the sectoral structure of industry in Poland is becoming similar to the structure of the highly developed EU countries such as France and the United Kingdom, which from the point of view of the objectives of economic transformation should be considered as a phenomenon of great benefit;

- however, still the most technologically advanced industry sectors have a relatively small share in the structure of the industry, which, as indicated by earlier studies, may be associated with low level of innovativeness of the Polish economy and the low level of spending on research and development compared with other EU countries;

- analysis of the spatial structure changes of the industry of Poland still shows a large share of industry in the economy of the regions; high location ratios were recorded in the traditionally highly industrialised voivodeships of south-western and central Poland;

- the process of industry deconcentration is noticeable, particularly in Śląskie Voivodeship; however, industrial capacity does not shift towards the peripheral voivodeships of minor importance for industry in the economy, but to the regions with traditionally strong industrial potential, such as Dolnośląskie, Wielkopolskie and Łódzkie;

- changes in the spatial structure of the industry indicate deepening interregional disparities in the development of the industry rather than reducing them; this indicates difficulties in the implementation of regional policy, which in its assumption should enhance inter-regional cohesion and lead to levelling of contrasts in the development of individual regions; as shown by previous studies, the instrument of special economic zones, which was to favour it, did not fulfil its role;

- foreign capital had a large role - generally positive in terms of economic effects in the processes of privatisation, industrial restructuring and the transformation of its branch structure; however, it did not contribute much to change the spatial structure of the industry, as it tended to concentrate in large urban areas, mainly in major metropolitan areas;

- as a result, concentration of industrial activity in the traditionally highly industrialised industrial districts is observed, mainly in the metropolitan areas of the Upper Silesian Industrial District, Poznań, Wrocław, Łódź, as well as partly in Warsaw, Kraków and Tri-City.

The changes in the spatial and branch structure have a very evolutionary pace, which is seen especially in the regional (voivodeships) level. These changes are more visible at a supra-local level (poviats); significant changes in the functioning of one very large company or a group of large companies, especially in the conditions of the global economic crisis, are well visible in spatial systems of low potential. The traditional strong industrial 
centers of large cities (especially those on the rights of urban poviats) such changes had no significant effect on the concentration of industry in their area. This reflects the relatively high 'inertia' of this sector of the economy, including the recent recession in the world economy, which very moderately affected Polish industry, as already identified in previous papers (Rachwał 2011, 2014).

Analysing the structural changes in the industry of Poland against European or global industry it is worth noting the much discussed issue of reindustrialisation, not only of Poland, but also other European countries. The economic crisis demonstrated that such action is necessary in order to increase innovativeness and boost economic development, including the reduction of the unemployment rate. Several years ago, pointing to the need for reindustrialisation in the public discourse would have been seen as something ridiculous. It turned out, however, that the countries that have gradually resigned from industrial activities in favour of services, did not always cope in the conditions of modern economy, particularly in times of crisis, which also showed that markets were not sufficiently effective. Realising the historical experience (e.g. the rapid development of Finland or Ireland in the second half of the twentieth century), and awareness of the limitations of interpretation of contemporary economic changes in the light of the theory of the three sectors (as pointed out in previous papers), it is clear that such reindustrialisation seems necessary, if based on modern, innovative knowledge-intensive branches of industry.

The above is confirmed by the experiences of the countries of Central and Eastern Europe, which in the second phase of the transition period maintained or even increased their industrial potential, which positively translated into the results of the whole economy. The reindustrialisation policy was also included in the industrial policy objectives set out in the EU development strategy by 2020 (European Commission 2010; cf. Ambroziak 2014; Heymann, Vetter, 2013). After Gawlikowska-Hueckel (2014), a clear evolution of the European Commission's approach to industry should be noted, resulting in the reindustrialisation process being supported by the cohesion policy via financing smart strategies and investments, also in the industrial sector. However, as the author concludes, actions envisaged in the strategy may not be effective, because the development of a modern, European industry will depend mainly on localisation preferences of corporations which in the conditions of globalisation have become independent players and decide on the location according to their interests. Unfortunately, in the light of the key documents on the industrial policy of Poland, there is no clear statements that would confirm a high priority of industry; instruments of the sectoral type that could lead to its revival have not been identified, although the legitimacy of sectoral interventions are indicated by independent experts (Gawlikowska-Hueckel 2014). Some of Poland's regions have a strong industrial base, so steps should be taken to further modernise it, improving its innovativeness and competitiveness. It seems however that the effects of these changes would be much greater with the support from the state industrial policy, which at this point seems too limited in relation to the objectives of reindustrialisation. The need to strengthen the institutional processes of reindustrialisation, especially outside metropolitan areas, was pointed out by Lux (2015). As Ambroziak (2014) noted, there is no solid legal basis upon which to establish common goals, instruments and institutional mechanisms of reindustrialisation policy; moreover this concept is economically questionable, and any new industrial policy should not be treated as a solution to all the problems in all Member States. It seems, however, that this new approach to industrial policy is right, given the important role of industry in the economy, even today in the postcrisis era. This policy should strengthen the competitiveness of European industrial companies, which play an important role in the development of a knowledge-based economy (Rachwał 2013). 
Finally, what needs stressing is a large involvement of Polish economic geographers in conducting research referring to the key problems of economic transition, especially the issue of changes in ownership, sectoral and spatial structure of industry, despite the difficulties in obtaining data, especially at the local and supra-local or individual entities data on the functioning of enterprises. Furthermore, these analyses, also of a geographical nature, are more and more often developed on the basis of other disciplines, mainly in economic sciences. This demonstrates the potential and viability of economic geography and maintaining the ability to deal with the challenges of new fields of research, also for the purposes of application of economic policy. Unfortunately, as noted by Stryjakiewicz (2014), industrial geographers had too

\section{References}

AmbroziaK A.A., 2014. Renaissance of the European Union's industrial policy. Yearbook of Polish European Studies, vol. 17/2014, Warsaw: Centre for Europe. University of Warsaw, pp. 37-58.

BAtToWSKI M., 2002. Przekształcenia własnościowe przedsiębiorstw państwowych w Polsce. Warszawa: Państwowe Wydawnictwo Naukowe.

Baranyal N., Lux G., 2014. Upper Silesia: The revival of a traditional industrial region in Poland. Regional Statistics, vol. 4, no. 2, pp. 126-144.

BazydŁo A., SmęTKowski M., Wieloński A., 2001. Inwestycje w specjalnych strefach ekonomicznych a przekształcenia strukturalne w przemyśle Polski. Prace Komisji Geografii Przemysłu PTG, 3, pp. 135-148.

BreZdeń P., 2006. Uwarunkowania bezpośrednie inwestycji zagranicznych i ich wpływ na umiędzynarodowienie działalności produkcyjnej w województwie dolnośląskim. Prace Komisji Geografii Przemysłu PTG, 8, pp. 60-73.

Chmurski M., Wieloński A., 2009. Restrukturyzacja polskiego przemysłu środków transportu szynowego na przykładzie przedsiębiorstwa small a share in formulating programmes of economic development and restructuring of regions and industrial branches, which resulted from many causes, including certain weaknesses of the Polish industrial geography. During the transition the Polish industrial geography was seeking new fields and research methods, because until 1989 there was no work in the literature relating to the transformation of socio-economic systems on such a scale that took place in Central and Eastern Europe at the turn of the twentieth and twenty-first century.

Editors' note:

Unless otherwise stated, the sources of tables and figures are the author's, on the basis of their own research.

Pojazdy Szynowe PESA Bydgoszcz SA. Prace Komisji Geografii Przemysłu PTG, 14, pp. 57-64.

Czapliński P., 2008. Problematyka badawcza przemystu w geografii na tle nauk ekonomicznych. Prace Komisji Geografii Przemysłu PTG, 11, pp. 46-52.

CZAPLIŃSKI P., 2011. Funkcjonowanie przemysłu przetwórstwa rybnego w Polsce w okresie kryzysu gospodarczego. Prace Komisji Geografii Przemysłu PTG, 17, pp. 114-128.

CZAPliński P., 2014. Processes of transformation of spatial structure of fish processing industry in Poland. Prace Komisji Geografii Przemysłu PTG, 25, pp. 151-162.

Czapliński P., Rachwat T., Tobolska A., UlisZAK R., 2013. Geografia gospodarcza. Poznań: Bogucki Wydawnictwo Naukowe.

Czapliński P., Stawarska A., 2010. Przejawy procesu globalizacji w sferze produkcji na przykładzie Scania Production Słupsk S.A. Prace Komisji Geografii Przemysłu PTG, 16, pp. 176-186.

CZEPCZYŃSKI M., 2001. Transformacja struktur przemysłowych na terenie województwa pomorskiego, Prace Komisji Geografii Przemysłu PTG, 3, pp. 87-91.

DomAŃSKI B., 1997. Geografia przedsiębiorstw niedoceniany nurt badań w polskiej geografii 
ekonomicznej [in:] B. Domański (ed.), Geografia - Człowiek - Gospodarka, Kraków: Instytut Geografii i Gospodarki Przestrzennej Uniwersytetu Jagiellońskiego, pp. 101-112.

DomańSKI B., 2001. Kapitał zagraniczny w przemyśle Polski, Kraków: Instytut Geografii i Gospodarki Przestrzennej Uniwersytetu Jagiellońskiego.

Domański B., 2002. Przemyst w rozwoju gospodarczym Małopolski [in:] Z. Górka, A. Jelonek (ed.), Geograficzne uwarunkowania rozwoju Małopolski, Kraków: Instytut Geografii i Gospodarki Przestrzennej Uniwersytetu Jagiellońskiego, pp. 69-84.

DOMAŃSKI B., 2003a. Industrial change and foreign direct investment in the postsocialist economy: The case of Poland. European Urban and Regional Studies, vol. 10, no. 2, pp. 99-118.

Domański B., 2003b. Transnational corporations in Polish manufacturing: Their embeddedness and impact on Poland's role in the European economy [in:] A. Kukliński, B. Skuza (ed.), Europe in the perspective of global change, Warsaw: The Polish Association for the Club of Rome, Oficyna Wydawnicza Rewasz, pp. 315-32.

Domański B., 2005. Transnational corporations and the postsocialist economy: Learning the ropes and forging new relationships in contemporary Poland [in:] C. Alvstam, E. Schamp (ed.), Linking industries across the World: Processes of Global Networking, Aldershot: Ashgate, pp. 147-172.

Domańskı B., GuzIK R., Gwosdz K., 2005. The new spatial organization of automotive industry in Poland in the context of its changing role in Europe, Studia Regionalia, vol. 15, pp. 153-171.

Domański B., GuzIK R., Gwosdz K., 2008, The new international division of labour and the changing role of the periphery: the case of the polish automotive industry [in:] Ch. Tamasy and M. Taylor (ed.), Globalising worlds and new economic configurations, Farnham: Ashgate, pp. 85-100.

Domański B., Guzik R., Gwosdz K., Dej M., 2013. The crisis and beyond: The dynamics and restructuring of automotive industry in Poland, International Journal of Automotive Technology and Management, vol. 13, no.2, pp. 151-166.

Domański B., Gwosdz K., 2005. Czynniki zakorzenienia inwestorów w strefie mieleckiej [in:] B. Domański, K. Gwosdz (red.), Dziesięć lat doświadczeń pierwszej polskiej specjalnej strefy ekonomicznej. Mielec 1995-2005, Kraków-Mielec: Instytut Geografii i Gospodarki Przestrzennej UJ, pp. 167-180.

Dyba W., Stryjakiewicz T., 2014. Inicjatywy klastrowe jako szansa rozwoju przemysłu meblarskiego w Polsce w warunkach kryzysu - przykład Swarzędzkiego Klastra Producentów Mebli. Prace Komisji Geografii Przemysłu PTG, 27, pp. 181-196.

European Commission, 2010. Europe 2020. A strategy for smart, sustainable and inclusive growth, Communication from the Commission. COM(2010) 2020, Brussels: European Council.

GaWlikowsKa-Heuckel K., 2014. Polityka przemysłowa i spójności wobec planów reindustrializacji Unii Europejskiej. Wnioski dla Polski. Gospodarka Narodowa, no. 5, pp. 53-80.

GierańcZYk W., 2000. Wpływ transformacji ustrojowej na zmiany strukturalne w przemyśle województwa toruńskiego. Prace Komisji Geografii Przemysłu PTG, 1, pp. 77-88.

GierańczYk W., RachWat T., 2012. Structural changes in the industry of Poland against the background of eastern European Union states. Quaestiones Geographicae, vol. 31, no. 2, pp. 83-93.

Gierańczyk W., Stańczyk A., 2001. Okręgi przemysłowe w Polsce u progu XXI wieku. Prace Komisji Geografii Przemysłu PTG, 3, pp. 61-69.

Gierańczyk W., Stańczyk A., 2003. Korporacje międzynarodowe w przestrzeni globalnej. Prace Komisji Geografii Przemysłu PTG, 5, pp. 73-84.

Gwosdz K., Huculak M., Jarczewski W., WiederMANN K., 2005. Specjalne strefy ekonomiczne w Polsce. Założenia a praktyka [in:] B. Domański, K. Gwosdz (ed.), Dziesięć lat doświadczeń pierwszej polskiej specjalnej strefy ekonomicznej, Mielec 1995-2005, Kraków-Mielec: Instytut Geografii i Gospodarki Przestrzennej Uniwersytetu Jagiellońskiego, Agencja Rozwoju Przemysłu P.A.

Hamm P., King L.P., Stuckler D., 2012. Mass privatization, state capacity, and economic growth in post-communist countries. American Sociological Review, vol. 77, no. 2, pp. 295-324.

Heymann E., Vetter S., 2013. Europe's reindustrialisation The gulf between aspiration and reality. Deutsche Bank Research EU Monitor - European integration. Frankfurt am Main: Deutsche Bank AG. 
Holland D., Pain N., 1998. The diffusion of innovations in Central and Eastern Europe: A study of the determinants and impact of foreign direct investment. NIESR Discussion Paper, 137. London: National Institute of Economic and Social Research.

IWAN C., 2005. Structural changes in the Polish sugar industry. Zuckerindustrie, vol. 130, no. 12, pp. 897-903.

JAżEWICZ I., Rydz E., 1994. Zmiany w funkcjonowaniu zakładów przemysłu spożywczego Słupska w latach 1985-1992 [in:] Z. Zioło (ed.), Funkcjonowanie przedsiębiorstw przemysłowych w zmieniajacych się warunkach gospodarowania, Materiały i Sprawozdania z. 28, Kraków - Warszawa: Centralny Ośrodek Metodyczny Studiów Nauczycielskich i Komisja Geografii Przemysłu PTG, pp. 125-138.

JENSEN C., 2002. Foreign direct investment, industrial restructuring and the upgrading of Polish exports. Applied Economics, vol. 34, no. 2, pp. 207-217.

Karpińska-MizielińsKa W., Smuga T., 1995. Proces przekształceń własnościowych w Polsce - próba oceny. Raporty IRiSS, 41, Gospodarka Polski w procesie transformacji, Warszawa: Instytut Rozwoju i Studiów Strategicznych.

KARPIŃSKI J., 1994. Zagraniczne inwestycje bezpośrednie w Polsce w okresie transformacji gospodarki. Zeszyty Naukowe. Seria 1. Akademia Ekonomiczna w Poznaniu, 222, pp. 58-69.

Kennedy R.E., 1997. A tale of two economies: Economic restructuring in post-socialist Poland. World Development, vol. 25, no. 6, pp. 841-865.

KILAR W., 2014. Zmiany potencjału ekonomicznego wybranych korporacji informatycznych w warunkach kryzysu gospodarczego. Prace Komisji Geografii Przemysłu PTG, 27, pp. 57-71.

KILAR W., 2015. Settlement concentration of economic potential represented by IT corporations, Geographia Polonica, vol. 88, no. 1, pp. 123-141.

KILAR W., RachWat T. 2014. Changing role of industry in the economy in the V4 countries - a regional approach. Theory, Methodology, Practice, vol. 10, no. 1, pp. 45-54.

Kilar W., Rachwat T., Wiedermann K., 2008. Changes in differentiation of Polish regions' industrial potential within the European Union, Europa XXI, 17, pp. 145-158.
KISS E., 1999. Recent organizational changes in Hungarian industry and their effects. Eastern European Economics. vol. 37, no. 3. pp. 34-58.

KISS E., 2002. Restructuring in the industrial areas of Budapest in the period of transition. Urban Studies. vol. 39, no. 1. pp. 69-85.

KIss E., 2003. Industrial parks in Hungary: Their furthering and role in regional economic development. Regional Symbiosis. vol. 11. pp. 47-64.

Kiss E., 2004. Spatial impacts of post-socialist industrial transformation in the major Hungarian cities. European Urban and Regional Studies, vol. 11, no. 1. pp. 81-87.

Kiss E., 2007a. Foreign direct investment in Hungary: Industry and its spatial effects. Eastern European Economics. vol. 45, no. 1, pp. 6-28.

KIsS E., 2007b. The impacts of relocation on the spatial pattern to Hungarian industry. Geographia Polonica, vol. 80, no. 1, pp. 43-63.

Kiss E., 2012. The impacts of the economic crisis on the spatial organization of Hungarian industry. European Urban and Regional Studies, vol. 19, no. 1, pp. $62-76$.

KITOWSKI J., 2009. Influence of global economic crisis on operation of special economic zones in Poland [in:] J. Kitowski (ed.), Countries of Central \& Eastern Europe versus global economic crisis, Geopolitical Studies, vol. 15, Warsaw: Institute of Geography and Spatial Organization PAS, pp. 241-267.

KOMORNICKI T., 2006. Eksport w ujęciu regionalnym jako miernik rozwoju przemysłu. Prace Komisji Geografii Przemysłu PTG, 8, pp. 167-178.

Lee M., NziRamasanga M., Ahn S.K., 2004. Transformation strategy and economic performance - Hungary and Poland. Eastern European Economics, vol. 42, no. 1, pp 25-42.

Lengyel I., 2014. Reorganizing of Hungarian manufacturing sector: Impacts of EU accession and global crises. European Journal of Business Research, vol. 14, no. 2, pp. 93-100.

Lux G., 2009a. Divergent patterns of adaptation among Central European old industrial regions. European Spatial Research and Policy, vol. 16, no. 1, pp. 145-157.

Lux G., 2009b. The re-emerging role of industry in Central European economies [in:] B. Baranyi, I. Fodor (eds.), The role of environmental industry in the regional reindustrialisation in Hunga- 
ry, Debrecen-Pécs: Hungarian Academy of Sciences Centre for Regional Studies, pp. 19-34.

Lux G., 2010. Location differences of services and industry: A Central European dichotomy. Prace Komisji Geografii Przemysłu PTG, 16, pp. 29-37.

Lux G., 2015. The institutional conditions of reindustrialization in post-crisis Central Europe. Journal of Economics \& Management, vol. 19, pp. 16-33.

Michalíková E., Galeotti E., 2011. Determinants of $F D I$ in Czech manufacturing industries between 2000-2007. South East European Journal of Economics and Business, vol. 5, no. 2, pp. 21-32.

Misztal P., 1993. Regionalne zróżnicowanie procesu prywatyzacji przemysłu w Polsce. Przegląd Geograficzny, vol. 65, no. 3, pp. 255-277.

Misztal P., 1996. Transformacja strukturalna w przemyśle Warszawy [in:] Z. Zioło (ed.), Wpływ procesów transformacji gospodarki narodowej na funkcjonowanie jednostek gospodarczych i układów przestrzennych, Warszawa-Kraków: Komisja Geografii Przemysłu PTG, Instytut Geografii Wyższej Szkoły Pedagogicznej, pp. 12-18.

Misztal P., 2000. Regionalne efekty procesu prywatyzacji przemysłu w Polsce w latach 19891995. Prace Komisji Geografii Przemysłu PTG, 1, pp. 23-34.

Misztal P., 2003. Transformacja własnościowa działalności przemysłowej w Polsce według województw. Prace Komisji Geografii Przemysłu PTG, 5, pp. 9-30.

MrozińSKA A., 2013. Zmiany strukturalne w przemyśle przetwórczym według województw w latach 1999-2010. Prace Komisji Geografii Przemysłu PTG, 21, pp. 157-172.

MSP, 2015. Przekształcenia własnościowe, stan na dzień 31 grudnia 2014 roku. Warszawa: Ministerstwo Skarbu Państwa, http://bip.msp. gov.pl/bip/raporty-analizy/przeksztalceniawlasnos/9470, stan-na-dzien-31-grudnia-2014roku.html [20 May 2015].

NAMYŚLAK B., 2004. Kapitał zagraniczny w specjalnych strefach ekonomicznych w Polsce. Prace Komisji Geografii Przemysłu PTG, 7, pp. 25-30.

PaKUŁa L., 2003. Tendencje restrukturyzacji przemysłu Górnoślaskiego Okręgu Przemysłowego w dobie transformacji. Prace Komisji Geografii Przemysłu PTG, 6, pp. 59-66.
PARYSEK J. J., 1993a. Stare i nowe problemy badawcze geografii przemysłu [in:] Z. Zioło (ed.), Regionalne problemy uprzemysłowienia, Materiały i Sprawozdania, 27, Kraków: Centralny Ośrodek Metodyczny Studiów Nauczycielskich, Komisja Geografii Przemysłu PTG, Wyższa Szkoła Pedagogiczna, pp. 8-19.

PARYSEK J.J., 1993b. O pewnym podejściu do delimitacji Okręgów Przemysłowych [in:] Z. Zioło (ed.), Problematyka Okręgu Przemysłowego w akademickim kształceniu nauczycieli geografii, Materiały i Sprawozdania, 26, Kraków: Centralny Ośrodek Metodyczny Studiów Nauczycielskich, Komisja Geografii Przemysłu PTG, Wyższa Szkoła Pedagogiczna, pp. 9-22.

PARYSEK J.J., 1994. Zachowania przestrzenne przedsiębiorstw przemysłowych w nowych warunkach społeczno-ustrojowych (na przykładzie Swarzędzkich Fabryk Mebli S.A.) [in:] Z. Zioło (ed.), Funkcjonowanie przedsiębiorstw przemysłowych w zmieniajacych się warunkach gospodarowania, Materiały i Sprawozdania, 28, Kraków-Warszawa: Centralny Ośrodek Metodyczny Studiów Nauczycielskich, Komisja Geografii Przemysłu PTG, pp. 22-30.

PAsZKOWSKI M., 1997. Przekształcenia strukturalne przemysłu krajów Europy Środkowo-Wschodniej na tle tendencji światowych [in:] Z. Zioło (ed.), Problemy transformacji struktur przemysłowych w procesie przechodzenia do gospodarki rynkowej, Kraków-Warszawa: Komisja Geografii Przemysłu PTG, Instytut Geografii Wyższej Szkoły Pedagogicznej, pp. 221-229.

Pavlínek P., 2004. Regional development implications of foreign direct investment in Central Europe. European Urban and Regional Studies, vol.11, no. 1, pp. 47-70.

PaVlíneK P., 2006. Restructuring of the Polish passenger car industry through foreign direct investment. Eurasian Geography and Economics, vol. 47, no. 3, pp. 353-377.

Pavlínek P., Domański B., Guzik R., 2009. Industrial upgrading through foreign direct investment in Central European automotive manufacturing. European Urban and Regional Studies, vol. 16, no. 1, pp. 43-63.

PIASECKA K., 2001. Skala i struktura inwestycji zagranicznych w polskim przemyśle. Prace Komisji Geografii Przemysłu PTG, 2, pp. 65-74.

RACHWAt T., 2003. Globalne uwarunkowania restrukturyzacji przedsiębiorstw Polski 
Południowo-Wschodniej. Prace Komisji Geografii Przemysłu PTG, 6, pp. 129-138.

RACHWAt T., 2006. Efekty restrukturyzacji wybranych przedsiębiorstw przemysłowych Polski Południowo-Wschodniej. Prace Komisji Geografii Przemysłu PTG, 9, pp. 98-115.

RaChWat T., 2008. Problematyka badawcza funkcjonowania przedsiębiorstw przemysłowych. Prace Komisji Geografii Przemysłu PTG, 11, pp. 53-85.

Rachwat T., 2010a. Problematyka badawcza zmian powiqzań przestrzennych przedsiębiorstw przemysłowych [in:] T. Kudłacz, J. Wrona (eds.), Geografia w naukach ekonomiczno-przestrzennych, Studia i Prace Uniwersytetu Ekonomicznego w Krakowie, 8, pp. 157-176.

RaCHWAt T., 2010b. Struktura przestrzenna i działowa przemysłu Polski na tle Unii Europejskiej $w$ dwudziestolecie rozpoczęcia procesów transformacji systemowej. Prace Komisji Geografii Przemysłu PTG, 16, pp. 105-124.

RaChwat T., 2011a. Wpływ kryzysu na zmiany produkcji przemysłowej w Polsce. Prace Komisji Geografii Przemysłu PTG, 17, pp. 99-113.

Rachwat T., 2011b. Transformations of the employment structure as an expression of the transformation of the Polish industry against the background of the European Union. Bulletin of Geography. Socio-economic Series, vol. 15, no. 15 , pp. $5-25$.

RaChWAt T., 2011c. Industrial restructuring in Poland and other European Union states in the era of economic globalisation. Procedia: Social and Behavioral Sciences, 19, pp. 1-10.

RACHWAt T., 2013. Rola przedsiębiorstw przemysłowych w rozwoju gospodarki opartej na wiedzy, Prace Komisji Geografii Przemysłu PTG, 21, pp. 189-211.

RACHWAt T., 2014. Zmiany strukturalne przemysłu Polski w warunkach kryzysu gospodarczego. Prace Komisji Geografii Przemysłu PTG, 27, pp. 148-163.

Rachwat T., Wiedermann K., 2008. Multiplier effects in regional development: The case of the motor vehicle industry in Ślaskie voivodeship (Poland). Quaestiones Geographicae, vol. 27, no. 1, pp. 67-80.

Rachwat T., Wiedermann K., Kilar W. 2008. Wydajność i koszty pracy jako czynniki konkurencyjności przemysłu regionów Polski w Unii
Europejskiej w ujęciu regionalnym [in:] D. Innicki, K. Janc (eds.), Przekształcenia regionalnych struktur funkcjonalno-przestrzennych: „Europa bez granic - nowe wyzwania”, Wrocław: Instytut Geografii i Rozwoju Regionalnego Uniwersytetu Wrocławskiego, pp. 79-90.

RachWat T., Wiedermann W., Kilar W., 2009. Rola przemysłu w gospodarce regionów Unii Europejskiej. Prace Komisji Geografii Przemysłu PTG, 14, pp. 31-42.

RAŹNIAK P., WINIARCZYK-RAŹNIAK A., 2015. Did the 2008 global economic crisis affect large firms in Europe? Acta Geographica Slovenica, vol. 55, no. 1, pp. 127-139.

Rochnowski H., 1993. Analiza porównawcza struktur gałęziowych przemysłu miast i terenów wiejskich obszaru Dolnej Wisły według podstawowych i relatywnych kategorii opisu [in:] Z. Zioło (ed.), Regionalne problemy uprzemysłowienia, Materiały i Sprawozdania, 27, Kraków: Centralny Ośrodek Metodyczny Studiów Nauczycielskich, Komisja Geografii Przemysłu PTG, Wyższa Szkoła Pedagogiczna w Krakowie, pp. 69-83.

Rochnowski H., 2000. Niektóre kierunki, cele i uwarunkowania przemysłu Polski w okresie transformacji. Prace Komisji Geografii Przemysłu PTG, 1, pp. 45-53.

SMĘTKOWSKI M., 2008. Rola specjalnych stref ekonomicznych w kształtowaniu struktury przestrzennej przemysłu w Polsce. Prace Komisji Geografii Przemysłu PTG, 10, pp. 204-216.

StRYJAKIEWICZ T. (ed.), 2005. Impact of foreign investors on regional and local development: The case of GlaxoSmithKline Pharmaceuticals S.A. in Poznań, Poznań: Bogucki Wydawnictwo Naukowe.

StryjakieWicz T., 1994. Próba analizy i oceny procesów transformacji przemystu w Polsce w świetle postfordowskiego modelu elastycznej produkcji i teorii regulacji [in:] Z. Zioło (ed.), Zachowania przestrzenne przemysłu w zmieniajacych się warunkach gospodarowania, Kraków-Warszawa: Komisja Geografii Przemysłu PTG, pp. 48-66.

Stryjakiewicz T., 1999. Adaptacja przestrzenna przemysłu w Polsce w warunkach transformacji. Poznań: Wydawnictwo Naukowe Uniwersytetu im. A. Mickiewicza.

StryjakieWICz T., 2001a. Orientacje teoretyczno-metodologiczne $w$ geografii przemysłu 
a transformacja gospodarki. Prace Komisji Geografii Przemysłu PTG, 3, pp. 13-27.

StryJAkIEWICZ T., 2001b. Koncepcja usieciowienia w badaniach przestrzenno- ekonomicznych [in:] H. Rogacki (ed.), Koncepcje teoretyczne i metody badań geografii społeczno-ekonomicznej. Poznań: Bogucki Wydawnictwo Naukowe, pp. 29-39.

StryjakieWICz T., 2014. Changes in Polish industrial geography at the turn of the 21st century. Prace Komisji Geografii Przemysłu PTG, 25, pp. 7-19.

SzCZEPKOWSKA M., 2003. Funkcjonowanie przedsiębiorstw w ramach grup kapitałowych na przykładzie Narodowych Funduszy Inwestycyjnych [in:] K. Piech, G. Szczodrowski (ed.), Przemiany i perspektywy polskich przedsiębiorstw w dobie integracji z Uniq Europejska, Warszawa: Instytut Wiedzy, pp. 201-214.

ŚLESZYŃSKI P., 2007., Gospodarcze funkcje kontroIne w przestrzeni Polski. Prace Geograficzne, 213, Warszawa: Instytut Geografii i Przestrzennego Zagospodarowania PAN.

ŚLESZYŃSKI P., 2008. Duże przedsiębiorstwa w strukturze przestrzennej największych polskich miast. Prace Geograficzne, 217, Warszawa: Instytut Geografii i Przestrzennego Zagospodarowania PAN.

ŚLESZYŃSKI P., 2010. Powiq̨zania organizacyjne i właścicielskie przedsiębiorstw przemysłowych $i$ usługowych w Polsce oraz ich znaczenie dla rozwoju regionalnego. Prace Komisji Geografii Przemysłu PTG, 15, pp. 117-129.

ŚLESZYŃSKI P., 2014. Headquarters of large enterprises in the spatial structure of major Polish cities. Prace Komisji Geografii Przemysłu PTG, 25, pp. 178-193.

TiCHÁ M., 2012. State or private ownership? A survey of empirical studies. Review of Economic Perspectives, vol. 12, no. 2, pp. 120-144.

Tkocz M., 2001. Restrukturyzacja przemysłu regionu tradycyjnego. Prace Naukowe Uniwersytetu Śląskiego, 1998. Katowice: Uniwersytet Śląski.

Tkocz M., 2006. Efekty restrukturyzacji górnictwa węgla kamiennego w Polsce. Prace Komisji Geografii Przemysłu PTG, 9, pp.28-39.

ToBolskA A., 1994. Funkcjonowanie "Amino" S.A. w zmieniajacych się warunkach ekonomicznych i społecznych [in:] Z. Zioło (ed.), Funkcjonowanie przedsiębiorstw przemysłowych w zmie- niajacych się warunkach gospodarowania, Materiały i Sprawozdania, 28, Kraków-Warszawa: Centralny Ośrodek Metodyczny Studiów Nauczycielskich i Komisja Geografii Przemysłu PTG, pp. 158-163.

Tobolska A., 2004. Procesy koncentracji gospodarczej dużych przedsiębiorstw przemysłowych Poznania. Prace Komisji Geografii Przemysłu PTG, 7, pp. 31-42.

TobOLSKA A., 2014. Choice of locations by foreign investors: Motives for and factors of starting a manufacturing activity (the example of selected factories in Poland). Prace Komisji Geografii Przemysłu PTG, 25, pp. 230-250.

WDOWICKA M., 2002. Wykształcanie się nowych obszarów przemysłowych w strefie podmiejskiej Poznania. Prace Komisji Geografii Przemysłu PTG, 3, pp. 115-122.

Wiedermann K., 2002. Restrukturyzacja i modernizacja hutnictwa żelaza Górnośląskiego Okręgu Przemysłowego po 1989 roku. Prace Komisji Geografii Przemysłu PTG, 4, pp. 115-128.

Wieloński A., 2000. Geografia przemysłu. Warszawa: Państwowe Wydawnictwo Naukowe.

Wieloński A., 2010. Wielkość i struktura eksportu miara konkurencyjności polskiego przemysłu. Prace Komisji Geografii Przemysłu PTG, 15, pp. 99-104.

Wieloński A., Durydiwka M., 1994. Przemyst w Polsce w warunkach przejścia do gospodarki rynkowej i integracji z Europq Zachodnia. Czasopismo Geograficzne, vol. 65, no. 3-4, pp. 317-325.

Wóstowicz M., Rachwat T., 2014. Globalisation and new centers of automotive manufacturing - the case of Brazil, Mexico, and Central Europe. Prace Komisji Geografii Przemysłu PTG, 25, pp. 81-107.

Zı૦Ło Z., 1992. Współczesne przesłanki rozwoju geografii przemysłu w warunkach zmieniajacego się systemu gospodarowania [in:] Z. Zioło (ed.), Geografia przemysłu w warunkach nowego systemu gospodarowania-problemy badawcze i odzwierciedlenie ich w kształceniu nauczycieli, Kraków-Warszawa: Centralny Ośrodek Metodyczny Studiów Nauczycielskich, Wyższa Szkoła Pedagogiczna, Komisja Geografii Przemysłu PTG, pp. 6-19.

ZıoŁo Z., 2003. Kształtowanie się przedsiębiorstw przemysłowych $w$ procesie globalizacji. Prace Komisji Geografii Przemysłu PTG, 6, pp. 9-20. 
ZıoŁo Z., 2008. Problemy badawcze struktury przestrzennej przemysłu, Prace Komisji Geografii Przemysłu PTG, 11, pp. 9-25.

ZıoŁo Z., 2009. Procesy kształtowania się światowych korporacji i ich wpływ na otoczenie. Prace Komisji Geografii Przemysłu PTG, 12, pp. 11-32.

ZıoŁo Z., 2010. Uwarunkowania kształtowania się procesów transformacji przemysłu i usług. Prace Komisji Geografii Przemysłu PTG, 15, pp. 45-60.

ZıoŁo Z., 2011. Wpływ światowego kryzysu na tempo wzrostu gospodarki i światowych korporacji. Prace Komisji Geografii Przemysłu PTG, 17, pp. 9-32.

ZıoŁo Z., 2013. Uwarunkowania kształtowania się procesów transformacji przemysłu i usług. Prace Komisji Geografii Przemysłu PTG, 15, pp. 45-60.

ZııŁO Z., 2014a. Development of enterprises in the spatial structure of industry (Based on research of the Industrial Geography Commission of the Polish Geographical Society). Prace Komisji Geografii Przemysłu PTG, 25, pp. 20-37.
ZıoŁo Z., 2014b. Wpływ kryzysu na kształtowanie struktury przestrzennej przemysłu. Prace Komisji Geografii Przemysłu PTG, 27, pp. 9-37.

ZıoŁo Z., Rachwat T. (eds.), 2014. Problematyka 30. Jubileuszowej Międzynarodowej Konferencji Naukowej nt. "Problematyka badawcza przemian strukturalnych przemysłu i usług w układach przestrzennych" / Main Theme of 30th Jubilee International Scientific Conference on "Structural Transformations of Industry and Services in Spatial Systems - Research-related Issues", Kraków-Warszawa: Zakład Przedsiębiorczości i Gospodarki Przestrzennej Instytutu Geografii Uniwersytetu Pedagogicznego im. Komisji Edukacji Narodowej, Komisja Geografii Przemysłu PTG.

ZıoŁo Z., Rachwat T., 2008. Komisja Geografii Przemysłu Polskiego Towarzystwa Geograficznego. Czasopismo Geograficzne, vol. 79, no.1-2, pp. 189-196. 
http://rcin.org.pl 